\title{
Social and Economic Costs of Inequality in the State of Virginia
}

\author{
Lawrence M. Eppard, Shippensburg University \\ Erik Nelson, Brigham Young University \\ Michael McLaughlin, Illinois Wesleyan University \\ Theresa Ward, Shippensburg University
}

\begin{abstract}
This study examined selected social and economic costs of inequality in the state of Virginia. We explored the extent of inequality of place across the state, finding significant inequalities between counties on measures such as household income, poverty, college completion, single parenthood, and racial segregation. These inequalities of place were strongly associated with inequalities in the adult outcomes of children raised in different areas of the state, including unequal household income and unequal rates of upward mobility, college completion, incarceration, and marriage in adulthood. When examining the association between homicides and concentrated disadvantage in the capital city of Richmond, our mapping techniques demonstrated a strong association. Finally, we estimated that child poverty results in billions of dollars of economic costs to the state each year.
\end{abstract}

\section{Keywords}

Neighborhoods, communities, concentrated disadvantage, social mobility, inequality, Virginia, United States, child poverty, violence, poverty, life chances

\section{Introduction}

There has been a considerable amount of attention given to inequality-related issues in the United States in recent years, from the rise of multiple populist political candidates to the Black Lives Matter movement to Occupy to \#MeToo to a variety of progressive policy proposals and beyond. ${ }^{1}$ A reasonable case could be made that this attention is warranted, given the available data. The top $10 \%$ of Americans owns $71 \%$ of the wealth and earns $46 \%$ of the income, compared to less than $2 \%$ (wealth) and $13 \%$ (income) for the bottom 50\% (WID 2021). The Gini coefficient (0.390), relative poverty rate $(18 \%)$, and relative child poverty rate $(21 \%)$ in the U.S. are all higher than most wealthy OECD countries with recent data available (OECD 2021a \& 2021b). Despite significant progress since the 1960s, African Americans still lag behind Whites ${ }^{2}$ in terms of the percentage of household income that they earn (61\% of Whites' income) and the wealth that they own (13\%) (Wilson 2020; Kent \& Ricketts 2021). There has been significant progress on gender equality over this same time period as well, but

\footnotetext{
${ }^{1}$ Mitt Romney's proposed Family Security Act, for instance, shares many of the same principles as European-style child allowances, which might have been unheard of in past iterations of the GOP. See his plan here: https://www.romney.senate.gov/sites/default/files/2021-02/family\%20security\%20act_one\%20pager.pdf .

2 Throughout this article, we capitalize Black as a sign of respect and we capitalize White, in the words of Eve L. Ewing, to avoid giving Whiteness power by allowing it to remain supposedly neutral and invisible, to avoid 'reinforcing the dangerous myth that White people in America do not have a racial identity. . . Whiteness is not only an absence. . Rather, it is a specific social category that confers identifiable and measurable social benefits' (Ewing 2020). We realize there is considerable debate about capitalization, and this is certainly not the only manner in which to handle this use of language. We do not make this language choice lightly, and our choice is not authoritative.
} 
again much work remains, with full-time female workers making around $80-84 \%$ of their male counterparts' earnings (depending upon how those earnings are measured) (Blau \& Kahn 2017; Eppard \& Blau 2020; Federal Reserve Bank of St. Louis 2021a \& 2021b). In this article we explore selected social and economic costs of allowing inequality to persist, focusing specifically on the state of Virginia. Examining all inequality measures would be beyond the scope of a single study, so we narrowed our inquiry to selected social costs of inequalities of place and the economic costs of child poverty.

\section{Literature Review}

\section{Inequality between American Neighborhoods and Communities}

There has been considerable growth in empirical evidence linking the unequal characteristics of place (neighborhoods, communities, counties, commuting zones, etc.) and inequalities in the adult outcomes of children raised in these different conditions. This association has received particular attention due to studies utilizing big data (such as the seminal work of Chetty et. al. 2014). As Sharkey and Faber note in their review of the literature, the 'American system of stratification is organized, in part, along spatial lines' and 'the spatial dimension of American inequality plays an important role in the maintenance and reproduction of inequality across multiple dimensions' (2014, p. 572).

The extant literature implicates several features of residential conditions ${ }^{3}$ in connection with the life chances of people raised there, including (but not limited to) the socioeconomic profile of the neighborhood/community, degree of economic inequality, degree of racial segregation, the presence/quality of neighborhood/community institutions (including schools, childcare providers, healthcare providers, churches, police, social service providers, parks, and civic associations), the stability of the neighborhood population, available peer networks, adult supervision/role models in the area, ${ }^{4}$ social cohesion (including trust, collective efficacy, social support, social connectedness, shared norms and expectations, and formal and informal social controls), presence of violence and/or gangs, exposure to pollution and other environmental burdens, predominant family structures, local marriage markets, local labor markets, characteristics of nearby neighborhoods, rates of foreclosures/vacancies/evictions, perceptions of neighborhood order/disorder, ${ }^{5}$ and housing density, among other characteristics.

\section{Inequality of Place and Upward Mobility}

Inequality of place is heavily implicated in the likelihood of upward mobility for Americans across the life course. As Putnam notes, 'researchers have steadily piled up evidence of how important social context, social institutions, and social networks - in short, our communities_-remain for our well-being and our kids' opportunities' (2015,

\footnotetext{
${ }^{3}$ We use 'residential conditions' throughout to refer to neighborhoods and communities where American children are raised. Another term used in the literature is 'residential contexts' (see Sharkey \& Faber 2014).

${ }^{4}$ Sampson explains that, 'Seemingly banal acts such as the collective supervision of children and adult mentorship add up to make a difference' (2019, p.12).

${ }^{5}$ As Sackett explains, 'strong evidence indicates that shared perceptions of past disorder (that is, what people thought about a neighborhood years ago) are a better predictor of homicides in neighborhoods than are present levels of physical disorder' (2016). He goes on to discuss vacant lots and foreclosures, noting that, 'Vacancies and evictions can also lead to violent crime by destabilizing communities and creating venues for crime. A study of Pittsburgh found that violent crime increased by 19 percent within 250 feet of a newly vacant foreclosed home and that the crime rate increased the longer the property remained vacant. In 2016's Evicted, Desmond notes that Milwaukee neighborhoods in the mid-2000s with high eviction rates had higher violent crime rates the following year after controlling for factors including past crime rates. Desmond suggests that eviction affects crime by frustrating the relationship among neighbors and preventing the development of community efficacy that could prevent violence' (Sackett 2016).
} 
p. 206). ${ }^{6}$ This is particularly troubling given that the proportion of American families living in middle-income neighborhoods has been declining, while the proportion of families living in either poor or affluent neighborhoods has risen significantly over the last four decades (Bischoff \& Reardon 2014). Children raised amongst concentrated disadvantage tend to have worse economic outcomes and less upward mobility compared to their counterparts in more advantaged areas (Chetty 2014; Chetty et. al. 2014; Wolfers 2015; Sampson 2019; Eppard et. al. 2020a, 2020b, 2020c).

The big data developed and utilized by Chetty and his colleagues (2014) has been particularly instructive. Chetty and his colleagues found significant variations in rates of upward mobility across American commuting zones, variations strongly associated with single motherhood $(\mathrm{r}=-0.76)$, social capital $(\mathrm{r}=0.64)$, test score percentile $(\mathrm{r}$ $=0.59)$, income inequality $(\mathrm{r}=-0.58)$, fraction Black residents $(\mathrm{r}=-0.58)$, high school dropout rate $(\mathrm{r}=-0.57)$, fraction married $(\mathrm{r}=0.57)$, and fraction religious $(\mathrm{r}=0.52)\left(2014\right.$, Online Appendix Table VIII). ${ }^{7}$

In another important study, Chetty and his colleagues re-analyzed data from the Moving to Opportunity (MTO) experiment ${ }^{8}$ (Chetty et. al. 2015). They found that compared to children who did not move, children who moved when they were young fared better in the areas of college graduation rates, likelihood of marriage, likelihood of single parenthood, economic performance, and the quality of their adult neighborhood of residence. ${ }^{9}$

Living amongst concentrated disadvantage at the neighborhood/community level appears to be detrimental for children even if their own individual household is not particularly disadvantaged. Chetty and his colleagues, for instance, found that single parenthood was strongly associated with upward mobility for all children $(\mathrm{r}=-0.76)$, as well as for children who themselves had married parents $(\mathrm{r}=-0.66)(2014$, Online Appendix Figure XII). Sharkey found that even for children in families with incomes in the top three quintiles, growing up in a highpoverty versus a low-poverty neighborhood increases their chances of downward mobility by 52 percent (2009, p. 2).

\section{Inequality of Place and Children's Success}

Children raised amongst concentrated disadvantage tend to fare worse compared to children raised in moreadvantaged areas (Massey \& Denton 1993; Wilson 1996; Sampson et. al. 1999; Sampson et. al. 2002; Pebley \& Sastry 2008; Sharkey 2009; Sampson 2012; Sharkey 2013; Sharkey \& Faber 2014; Chetty et. al. 2015; Putnam 2015; Sharkey \& Sampson 2015; Rojas-Gaona et. al. 2016; Sampson \& Winter 2016; Sampson 2019; Eppard et. al. 2020a, 2020b, 2020c).

\footnotetext{
${ }^{6}$ Elsewhere he explains that 'growing class segregation across neighborhoods, schools, marriages (and probably also civic associations, workplaces, and friendship circles) means that rich Americans and poor Americans are living, learning, and raising children in increasingly separate and unequal worlds, removing the stepping-stones to upward mobility' (Putnam 2015, p. 41). ${ }^{7}$ Summarizing this work, Chetty explains: 'we find a strong negative correlation between standard measures of racial and income segregation and upward mobility. . These findings lead us to identify segregation as the first of five major factors that are strongly correlated with mobility. The second factor we explore is inequality. [Commuting zones] with larger Gini coefficients have less upward mobility, consistent with the 'Great Gatsby curve'. . Third, proxies for the quality of the K-12 school system are also correlated with mobility. . . Fourth, social capital indices - which are proxies for the strength of social networks and community involvement in an area - are very strongly correlated with mobility. . . Finally, the strongest predictors of upward mobility are measures of family structure such as the fraction of single parents in the area' (2014, pp. 5-6).

${ }^{8}$ The MTO was a 1990s federal government experiment which gave a number of American families who were living in public housing a voucher to move to better neighborhoods in order to see if it improved their lives.

${ }^{9}$ Summarizing this new analysis, Wolfers explains that: 'the next generation-the grandchildren of the winners of this lottery-are more likely to be raised by two parents, to enjoy higher family incomes and to spend their entire childhood in better neighborhoods. That is, the gains from this policy experiment are likely to persist over several generations' (2015).
} 
Compared to children raised in more advantaged areas, children in disadvantaged areas tend to develop worse cognitive skills, perform worse in school, and are less likely to complete high school and college (Bronzaft \& McCarthy 1975; Evans \& Maxwell 1997; Aaronson 1998; Plotnick \& Hoffman 1999; Leventhal \& Brooks-Gunn 2000; Duncan et. al. 2001; Harding 2003; Stansfeld et. al. 2005; Sampson et. al. 2008; Schwartz 2010; Sharkey 2010; Sharkey \& Elwert 2011; Wodtke et. al. 2011; Sastry 2012; Sharkey et. al. 2013; Sharkey \& Faber 2014; Hamner et. al. 2015). ${ }^{10}$ The extent of the negative impact is dependent upon the degree of neighborhood/community disadvantage, the period of childhood in which one is exposed, duration of exposure, which residential conditions one is exposed to, and individual vulnerability (Sharkey \& Faber 2014). ${ }^{11}$

Sharkey's (2013) data revealed that poverty experienced by a child or their parent can have a substantial impact on the child's cognitive skills. The gaps between children from families who had never experienced poverty and those who had experienced poverty across generations was the equivalent of missing three to four years of schooling. Children performed well above average on tests of cognitive skills when neither they nor any of their parents were raised in a high-poverty neighborhood. If the child or one of their parents (but not both the child and any of their parents) was raised in a high-poverty neighborhood, cognitive scores dropped considerably. Children's scores dropped considerably more — scoring well below average - if a child and at least one of their parents were raised in a high-poverty neighborhood (Sharkey 2013, p. 119).

Although there are a variety of neighborhood/community factors which impact cognitive skills, academic performance, and educational attainment, school quality is clearly important. Reardon (2016), for instance, found a strong association $(\mathrm{r}=0.78)$ between school district socioeconomic status and average academic achievement across the U.S.: 'Students in many of the most advantaged school districts have test scores that are more than four grade levels above those of students in the most disadvantaged districts' (2016, p. 7). Schwartz (2010) tracked the longitudinal school performance of students who, despite living in public housing in the same county, had been randomly assigned to housing in different neighborhoods and thus attended different schools. Children in the school district's most-advantaged schools performed far better in math and reading than children assigned to the district's least-advantaged schools. Burdick-Will et. al. (2011) found that children experienced significant improvements on a variety of assessments of cognitive skills, reading, and math after they moved out of areas of concentrated disadvantage. And Chetty and his colleagues (2014, Online Appendix Table VIII) found strong correlations between upward mobility rates and both test score percentiles $(r=0.59)$ and high school dropout rates $(r=-0.57)$ across U.S. commuting zones.

Disadvantaged residential conditions tend to have lower-quality institutions compared to more-advantaged areas (Small 2009; Schwartz 2010; Allard \& Small 2013; Chetty et. al. 2014; Sharkey \& Faber 2014; Putnam 2015; Future Ready PA Index 2021). In one such institution, schools, there is considerable variation in school environments and teacher quality across the U.S. In poor schools, students are more likely to interact with peers with a variety of characteristics which can negatively influence them, including lower expectations, fewer family resources to share, and less middle-class-approved behavior to model. Poor schools are also more likely to have to rely on less-experienced and/or less-effective teachers (Putnam 2015, pp. 172-173). Children raised amongst

\footnotetext{
${ }^{10}$ Wodtke and his colleagues (2011) found that being raised in a disadvantaged neighborhood reduced the probability of high school graduation by 10 to 20 percentage points. They found that the probability of graduation for Black children raised in the most disadvantaged neighborhoods instead of the most advantaged fell from 96 to 76 percent. They explained their findings: 'Our results indicate that sustained exposure to disadvantaged neighborhoods - characterized by high poverty, unemployment, and welfare receipt; many female-headed households; and few well-educated adults - throughout the entire childhood life course has a devastating impact on the chances of graduating from high school' (Wodtke et. al. 2011, p. 731).

${ }^{11}$ As Sharkey and Faber note, 'Individuals' residential environments are not experienced at a single point in time and then erased from their lives. Rather, there is strong evidence that the influence of the residential environment persists and accumulates, with consequences that extend over long periods of time and generations of families' (2014, p. 572).
} 
concentrated disadvantage are at greater risk for adverse physical and mental health outcomes, ${ }^{12}$ teen pregnancy, substance abuse, and criminal involvement and victimization (Peeples \& Loeber 1994; Wheaton \& Clarke 2003; Brady et. al. 2008; Sharkey \& Sampson 2010; Stoddard et. al. 2011; Eppard et. al. 2020b; CDPH 2021).

Environmental burdens are distributed along racial and socioeconomic lines in the U.S. (UCC 2007), ${ }^{13}$ and several researchers have demonstrated a link between these exposures and adverse outcomes. Some research, for instance, has established an association between exposure to environmental burdens like pollution, toxic waste, noise, and other burdens to inequalities in children's academic performance and educational attainment (Cohen et. al. 1973; Bronzaft \& McCarthy 1975; Cohen et. al. 1980; Hambrick-Dixon 1985; Ransom \& Pope 1992; Evans \& Maxwell 1997; Lanphear et. al. 2005; Stansfeld et. al. 2005; Evans 2006; Currie et. al. 2009; Reyes 2012), ${ }^{14}$ while others have explored how such exposure impacts children's health (Evans \& Kantrowitz 2002; Stansfeld et. al. 2005; Entwisle 2007; Currie et. al. 2011; Sampson 2019). ${ }^{15}$

\section{Inequality of Place and Violence}

One's likelihood of committing or being a victim of a violent crime is strongly influenced by their neighborhood/community. Violent crime tends to be geographically concentrated in neighborhoods/communities experiencing concentrated disadvantage. As Sampson notes, 'concentrated disadvantage remains a strong predictor of violent crime' (2019, p. 13). Sharkey and his colleagues similarly explain that, 'crime is clustered in space to a remarkable degree' (2016, p. 629). Sackett explains that, 'Concentrated disadvantage, crime, and imprisonment appear to interact in a continually destabilizing feedback loop' (2016). ${ }^{16}$

When Sharkey mapped homicides across Chicago, he found a 'strikingly visible' (2013, p. 30) overlap between concentrated disadvantage and homicide. ${ }^{17}$ Eppard and his colleagues (2020b) found a similar clustering of gun homicides in areas of concentrated disadvantage when mapping New York City, finding 'extraordinary overlap between clusters of gun homicides and areas of disproportionately high concentrations of Black residents,

\footnotetext{
${ }^{12}$ As Gourevitch explains, 'One's Zip code is as important to one's health as one's genetic code. . . Those lack of resources are the basic determinants of health' (Guarino 2021).

${ }^{13}$ In a 2007 report from the United Church of Christ, researchers found that neighborhoods with commercial hazardous waste facilities in the U.S. had poverty rates that were 1.5 times greater than non-host areas, and 1.8 times greater in neighborhoods with multiple facilities. In addition, host neighborhoods were 56 percent non-White, compared to 30 percent in non-host neighborhoods. In areas with multiple facilities, the percentage non-White was 69 percent (UCC 2007, pp. 53-54, 73).

${ }^{14}$ Bronzaft and McCarthy (1975), for instance, showed that at one NYC school, students in some of the classrooms closest to noise from a nearby elevated train were three to four months behind their peers on the quieter side of school.

${ }^{15}$ Sampson explains the association between the racial composition of Chicago neighborhoods and exposure to lead: 'Drawing on comprehensive data from over one million blood tests administered to Chicago children from 1995 to 2013 and matched to over 2,300 geographic block groups, we found that black and Hispanic neighbourhoods exhibited extraordinarily high rates of lead toxicity compared with white neighbourhoods, in some cases with prevalence rates topping 90\% of the child population' (2019, p. 14).

${ }^{16}$ Sackett goes on to explain that, 'Neighborhoods with more concentrated disadvantage tend to experience higher levels of violent crime. Numerous studies, for instance, show that neighborhoods with higher poverty rates tend to have higher rates of violent crime. Greater overall income inequality within a neighborhood is associated with higher rates of crime, especially violent crime. Sampson notes that even though the city of Stockholm has far less violence, segregation, and inequality than the city of Chicago, in both cities a disproportionate number of homicides occur in a very small number of very disadvantaged neighborhoods' (2016).

${ }^{17}$ He explains: 'the concentration of violence goes hand in hand with the concentration of poverty. There is a remarkable spatial clustering of homicides in and around neighborhoods with high levels of poverty. . . there are entire sections of this violent city where the most extreme form of violence, a local homicide, is an unknown occurrence. There are other neighborhoods where homicides are a common feature of life. . . these maps provide perhaps the most vivid portrait of what living in areas of concentrated poverty can mean in America's cities' (Sharkey 2013, p. 30).
} 
poverty, and single parenthood, and low concentrations of college graduates, high-income earners, and upwardlymobile residents' (2020b, pp. 25, 29). ${ }^{18}$

Even within crime-burdened neighborhoods/communities, violent crime is not evenly distributed but is instead concentrated within narrow social networks as well as geographic 'hot spots' or 'micro places.' In a study of Boston police records over an almost 30-year period, for instance, fewer than three percent of micro places accounted for a majority of all incidents of gun violence. In another study of Boston, researchers found that 85 percent of gunshot injuries occurred within a single network of people that represented less than six percent of the city's population (Sackett 2016).

Violence negatively impacts the fabric of a community, the health of its residents, and the development of its children and their future educational and economic performance. Research has shown a relationship between exposure to violence and children's cognitive development, academic performance, health, and adult economic performance (Harding 2009; Sharkey 2010; Cutsinger et. al. 2011; Sampson 2012; Sharkey et. al. 2013; Sharkey \& Faber 2014; Sharkey \& Sampson 2015; Sackett 2016; Sampson 2019).${ }^{19}$ Children living in neighborhoods with high crime rates tend to have significantly worse economic performance later as adults (Sackett 2016). Disadvantaged residential conditions are more likely to foster conditions where females are coerced into sex, are harassed, and/or are more likely to be victims of sexual violence, with negative consequences for their sexual development, mental health, and likelihood of substance abuse (Sackett 2016). And a number of studies have shown that moving children out of disadvantaged and dangerous residential contexts and into more advantaged and less dangerous ones can improve their life chances (Sharkey \& Faber 2014).

\section{The Economic Costs of Child Poverty}

Social scientists have long documented the manner in which poverty experienced early in life stunts children's development. Recently researchers have examined other impacts of child poverty, including its economic impact on the larger society. What they have found is that if children's capabilities and future potential across the life course are constrained by economic disadvantage, this then negatively impacts their economic productivity, health, and criminality in ways that create associated costs for the larger society. The Children's Defense Fund (1994) estimated that the annual economic costs of child poverty ranged from $\$ 36$ billion to $\$ 177$ billion due to the manner in which living in poverty during childhood suppressed individuals' educational attainment, development of job skills, and future economic productivity.

Holzer and his colleagues $(2007,2008)$ estimated that child poverty in the U.S. reduced the nation's economic output by $\$ 170$ billion per year, increased crime costs by $\$ 170$ billion per year, and increased health expenditures by $\$ 164$ billion per year-for a combined cost of around $\$ 500$ billion per year, which represented 3.8\% of GDP.

Garcia and his colleagues (2017) estimated that high-quality early childhood interventions yielded an annual return on investment of 13 percent over the life course of disadvantaged children, equaling a substantial societal profit over time. In a similar vein, McLaughlin and Rank (2018) estimated that for every dollar spent on reducing

\footnotetext{
${ }^{18}$ The authors go on to note that, 'Our analyses reveal that such overlap is present not only in New York City, but is typical in a number of American cities. . not only does violence overlap with all of these measures of disadvantage, but all of these measures of disadvantage overlap with each other. Research suggests that each individual dimension of disadvantage constrains people's agency in significant ways independently of other dimensions - so facing multiple dimensions, as these residents do, makes life significantly more difficult than facing any one dimension individually. Research suggests that it is areas like these, which are burdened with not just one but several disadvantages, where violence seems to crop up most' (Eppard et. al. 2020b, p. 29).

${ }^{19}$ Sharkey (2010) found that children perform substantially worse on assessments of cognitive skills administered within a week following a local homicide — likely due to the stress, shock, trauma, and/or fear caused by such an event—and that the negative effect was worse the closer the homicide was to their home.
} 
child poverty in the U.S., the country would save at least seven dollars with respect to the economic costs of poverty. They estimated the annual costs of childhood poverty in the U.S. to be over $\$ 1$ trillion, which represented 5.4 percent of GDP. These costs were the result of reduced adult earnings and the increased costs of crime, incarceration, healthcare, homelessness, and maltreatment associated with growing up poor. There has been little other research on the economic costs of child poverty, and none to our knowledge focusing on a specific U.S. state as in our analysis.

\section{Methods}

\section{Inequality of Place and Low-Income Children's Adult Success}

All quantitative data utilized in our analyses come from the publicly-accessible Opportunity Atlas database housed at Opportunity Insights (2021). This database contains U.S. Census Bureau data as well as anonymous federal tax return data for over 20 million Americans. It allows researchers to examine the association between community of origin characteristics ${ }^{20}$ (such as household income, poverty, college completion, racial composition, single parenthood, and a variety of economic/labor market indicators) and adult outcomes like household income, college graduation, incarceration, marriage, and upward mobility. We downloaded this publicly-accessible data and analyzed it using SPSS statistical software, which allowed us to construct descriptive tables, calculate multiple linear regression models, and graph bivariate scatterplots.

One of the many virtues of this database is that its data are available by demographic subgroup. Therefore, one can try to isolate the impact of place as much as possible by controlling for other variables, such as gender and household income. Due to a variety of considerations, ${ }^{21}$ we focused on low-income men (born between 19781983, raised in households at the $25^{\text {th }}$ income percentile, and tracked into their mid-thirties) in our analysis, exploring how the likelihood of success for an American from a low-income household can vary depending upon the neighborhoods and communities in which those households are situated.

First, we calculated multiple linear regression models determining which of the eleven origin county variables (college completion rate, share Black, employment rate, median household income, job density, job growth rate, math performance, poverty rate, single parenthood rate, wage growth, and social capital $)^{22}$ were most strongly associated with each of the five adult outcome variables (college completion rate, ${ }^{23}$ household income, ${ }^{24}$ incarceration rate, ${ }^{25}$ marriage rate,${ }^{26}$ and upward mobility rate ${ }^{27}$ ) across all U.S. counties with available data. Then, we constructed scatterplots to illustrate some of the strongest associations (in bivariate form). Next, we constructed tables illustrating how all Virginia counties ranked on the five adult outcomes. Then, we included a

\footnotetext{
${ }^{20}$ Units of analysis available in the Opportunity Atlas database were Census tract, county, and commuting zone. Even though commuting zones are perfectly acceptable units of analysis used by Chetty and others, we wanted something smaller and closer to 'neighborhood' size. In order to include the desired variables for this analysis the smallest unit available was county.

${ }^{21}$ One important consideration is that upward mobility processes may not be exactly the same for men and women, so combining them in the same analysis could be methodologically inappropriate. As one example, see the gender asymmetry demonstrated in Qian 2017. Another consideration is the impact of household income-by focusing on one income group, low-income men, instead of including all income levels, we control for household income's influence.

${ }^{22}$ For the definition of the social capital variable, see Opportunity Insights (2021).

${ }^{23}$ Fraction of low-income (25th percentile) male children who grew up in these areas who hold a bachelor's degree or higher in their mid-30s.

${ }^{24}$ Average household income for low-income male children who grew up in these areas when they reach their mid-30s.

${ }^{25}$ Fraction of low-income male children who grew up in these areas who were in prison/jail in their mid-30s.

${ }^{26}$ Fraction of low-income male children who grew up in these areas who were married in their mid-30s.

${ }^{27}$ Fraction of low-income male children who grew up in these areas whose household income was in the top $20 \%$ of national income in their mid-30s (national income measure based on children born the same year).
} 
heat map to illustrate variations in upward mobility across the state of Virginia. Finally, we constructed a table to illustrate the major inequalities in county characteristics present across the state of Virginia.

\section{Estimating the Economic Costs of Child Poverty}

Around 13\% of Virginia's children lived in poverty in 2019 (Stebbins 2020; AECF 2021). To calculate the economic cost of this child poverty for the state we used figures from our previous work in McLaughlin \& Rank (2018), which calculated the aggregate cost of child poverty for all fifty U.S. states in 2015. Using these figures as a starting point, we made adjustments for Virginia's share of each cost to derive Virginia's cost of child poverty for 2015. We then adjusted this figure for inflation to obtain Virginia's cost of child poverty for 2019.

\section{Mapping Concentrated Disadvantage and Violence}

Time and resource limitations did not allow us to analyze all major cities in the state of Virginia, so we focused on the state capital of Richmond. We obtained the Census tract characteristics (fraction Black residents, fraction college graduates, fraction poor, fraction single parents, and median income) and measures of low-income men's adult outcomes (fraction incarcerated, fraction married, and fraction upwardly mobile) for Richmond from the Opportunity Insights (2021) database. We divided each of these measures into equally-spaced quintiles to show the gradient of variation within each measure. We also obtained the locations of all homicides $(n=89)$ that occurred in the city between January 1, 2018 and November 30, 2020 (most current date at time of analysis) from the LexisNexis Community Crime Map (2020). Finally, we obtained Census tract boundaries (i.e., shapefiles) from the U.S. Census Bureau (2020) to visualize the data. More specifically, we created choropleth maps, as shown in Figure 6, to show the geographic variation in these measures in relationship to the homicide locations. All analyses were conducted using the ggplot 2 package in $\mathrm{R}$ version 3.5.2.

\section{RESULTS}

\section{Inequality of Place and Adult Outcomes}

There was significant inequality between counties in social mobility. The percentage of low-income men who rose to the top $20 \%$ in adulthood was as high as $21 \%$ in Fairfax County and as low as less than $2 \%$ in Petersburg City (see Table 1). As a state, Virginia does not appear to fare well compared to the rest of the country on mobility for low-income men, given that $84 \%$ (112 out of 133) of the counties in the state had mobility rates below the national average. In a multiple linear regression model with all eleven origin county characteristics included, county single parenthood rate proved to be the strongest predictor of mobility (see Table 2). The scatterplot in Figure 1 illustrates the bivariate association between county single parenthood rate and upward mobility $(r=-$ 0.50). Figure 2 illustrates the wide geographic variation in mobility rates for low-income men across Virginia counties. Note how mobility rates are low in most of the state outside of the affluent Northern Virginia region. 
Table 1. Virginia Counties Ranked by Upward Mobility Rates for Low-Income Men

\begin{tabular}{|c|c|c|}
\hline VIRGINIA COUNTY & $\begin{array}{c}\% \\
\text { UPWARDLY } \\
\text { MOBILE }\end{array}$ & $\begin{array}{c}\text { VA } \\
\text { MOBILITY } \\
\text { RANK }\end{array}$ \\
\hline U.S. county average & 9.92 & - \\
\hline Fairfax County, VA & 21.12 & 1 \\
\hline Loudoun County, VA & 20.29 & 2 \\
\hline Falls Church city, VA & 20.13 & 3 \\
\hline Fairfax city, VA & 20.00 & 4 \\
\hline Rappahannock County, VA & 19.09 & 5 \\
\hline Norton city, VA & 16.55 & 6 \\
\hline Clarke County, VA & 15.50 & 7 \\
\hline Manassas city, VA & 15.21 & 8 \\
\hline Arlington County, VA & 14.00 & 9 \\
\hline Poquoson city, VA & 13.89 & 10 \\
\hline Fauquier County, VA & 13.44 & 11 \\
\hline Colonial Heights city, VA & 13.37 & 12 \\
\hline Stafford County, VA & 12.18 & 13 \\
\hline Warren County, VA & 11.99 & 14 \\
\hline Prince William County, VA & 11.98 & 15 \\
\hline Alexandria city, VA & 11.63 & 16 \\
\hline Hanover County, VA & 11.14 & 17 \\
\hline Albemarle County, VA & 10.94 & 18 \\
\hline New Kent County, VA & 10.55 & 19 \\
\hline Buchanan County, VA & 10.40 & 20 \\
\hline Spotsylvania County, VA & 10.11 & 21 \\
\hline Craig County, VA & 9.87 & 22 \\
\hline York County, VA & 9.83 & 23 \\
\hline Powhatan County, VA & 9.77 & 24 \\
\hline Roanoke County, VA & 9.69 & 25 \\
\hline King and Queen County, VA & 9.61 & 26 \\
\hline Chesterfield County, VA & 9.57 & 27 \\
\hline Charlottesville city, VA & 9.44 & 28 \\
\hline Highland County, VA & 9.25 & 29 \\
\hline Alleghany County, VA & 9.14 & 30 \\
\hline Shenandoah County, VA & 9.11 & 31 \\
\hline Frederick County, VA & 8.88 & 32 \\
\hline Mathews County, VA & 8.83 & 33 \\
\hline Charles City County, VA & 8.79 & 34 \\
\hline Campbell County, VA & 8.64 & 35 \\
\hline Amelia County, VA & 8.62 & 36 \\
\hline James City County, VA & 8.43 & 37 \\
\hline Montgomery County, VA & 8.29 & 38 \\
\hline Westmoreland County, VA & 8.22 & 39 \\
\hline Northampton County, VA & 8.19 & 40 \\
\hline King George County, VA & 8.07 & 41 \\
\hline King William County, VA & 8.05 & 42 \\
\hline Page County, VA & 8.04 & 43 \\
\hline Floyd County, VA & 8.03 & $\mathrm{~T}-44$ \\
\hline Henrico County, VA & 8.03 & $\mathrm{~T}-44$ \\
\hline Orange County, VA & 7.99 & 46 \\
\hline
\end{tabular}




\begin{tabular}{|c|c|c|}
\hline Dickenson County, VA & 7.92 & 47 \\
\hline Harrisonburg city, VA & 7.87 & 48 \\
\hline Winchester city, VA & 7.84 & 49 \\
\hline Tazewell County, VA & 7.81 & 50 \\
\hline Accomack County, VA & 7.77 & 51 \\
\hline Culpeper County, VA & 7.76 & 52 \\
\hline Botetourt County, VA & 7.60 & 53 \\
\hline Northumberland County, VA & 7.48 & 54 \\
\hline Wise County, VA & 7.38 & 55 \\
\hline Virginia Beach city, VA & 7.34 & 56 \\
\hline Bedford County, VA & 7.31 & 57 \\
\hline Russell County, VA & 7.26 & 58 \\
\hline Lexington city, VA & 7.24 & 59 \\
\hline Hopewell city, VA & 7.22 & 60 \\
\hline Essex County, VA & 7.17 & 61 \\
\hline Madison County, VA & 7.15 & 62 \\
\hline Lancaster County, VA & 7.12 & 63 \\
\hline Appomattox County, VA & 7.09 & 64 \\
\hline Pittsylvania County, VA & 6.98 & 65 \\
\hline Chesapeake city, VA & 6.96 & 66 \\
\hline Williamsburg city, VA & 6.93 & 67 \\
\hline Rockingham County, VA & 6.83 & $\mathrm{~T}-68$ \\
\hline Manassas Park city, VA & 6.83 & $\mathrm{~T}-68$ \\
\hline Bland County, VA & 6.56 & 70 \\
\hline Bristol city, VA & 6.49 & 71 \\
\hline Nelson County, VA & 6.37 & 72 \\
\hline Cumberland County, VA & 6.34 & 73 \\
\hline Amherst County, VA & 6.27 & 74 \\
\hline Augusta County, VA & 6.25 & $\mathrm{~T}-75$ \\
\hline Fredericksburg city, VA & 6.25 & $\mathrm{~T}-75$ \\
\hline Isle of Wight County, VA & 6.19 & $\mathrm{~T}-77$ \\
\hline Washington County, VA & 6.19 & $\mathrm{~T}-77$ \\
\hline Gloucester County, VA & 6.16 & 79 \\
\hline Prince George County, VA & 6.13 & 80 \\
\hline Hampton city, VA & 6.12 & 81 \\
\hline Bath County, VA & 6.10 & 82 \\
\hline Franklin County, VA & 6.03 & 83 \\
\hline Louisa County, VA & 5.97 & 84 \\
\hline Prince Edward County, VA & 5.79 & 85 \\
\hline Rockbridge County, VA & 5.78 & 86 \\
\hline Buena Vista city, VA & 5.74 & 87 \\
\hline Salem city, VA & 5.67 & 88 \\
\hline Greene County, VA & 5.63 & 89 \\
\hline Franklin city, VA & 5.58 & 90 \\
\hline Patrick County, VA & 5.50 & 91 \\
\hline Goochland County, VA & 5.44 & 92 \\
\hline Staunton city, VA & 5.41 & 93 \\
\hline Galax city, VA & 5.40 & 94 \\
\hline Waynesboro city, VA & 5.39 & 95 \\
\hline Pulaski County, VA & 5.35 & 96 \\
\hline Lynchburg city, VA & 5.33 & 97 \\
\hline Covington city, VA & 5.31 & 98 \\
\hline Surry County, VA & 5.27 & 99 \\
\hline Halifax County, VA & 5.17 & 100 \\
\hline Newport News city, VA & 4.97 & 101 \\
\hline Charlotte County, VA & 4.90 & T-102 \\
\hline
\end{tabular}




$\begin{array}{lcc}\text { Grayson County, VA } & 4.90 & \mathrm{~T}-102 \\ \text { Mecklenburg County, VA } & 4.89 & 104 \\ \text { Suffolk city, VA } & 4.70 & 105 \\ \text { Brunswick County, VA } & 4.67 & 106 \\ \text { Southampton County, VA } & 4.64 & 107 \\ \text { Giles County, VA } & 4.56 & 108 \\ \text { Martinsville city, VA } & 4.49 & 109 \\ \text { Scott County, VA } & 4.42 & 110 \\ \text { Caroline County, VA } & 4.41 & \mathrm{~T}-111 \\ \text { Smyth County, VA } & 4.41 & \mathrm{~T}-111 \\ \text { Portsmouth city, VA } & 4.38 & 113 \\ \text { Radford city, VA } & 4.36 & 114 \\ \text { Henry County, VA } & 4.34 & 115 \\ \text { Buckingham County, VA } & 4.28 & \mathrm{~T}-116 \\ \text { Greensville County, VA } & 4.28 & \mathrm{~T}-116 \\ \text { Lee County, VA } & 4.28 & \mathrm{~T}-116 \\ \text { Nottoway County, VA } & 4.19 & 119 \\ \text { Sussex County, VA } & 4.18 & \mathrm{~T}-120 \\ \text { Norfolk city, VA } & 4.18 & \mathrm{~T}-120 \\ \text { Danville city, VA } & 4.14 & 122 \\ \text { Wythe County, VA } & 4.05 & \mathrm{~T}-123 \\ \text { Emporia city, VA } & 4.05 & \mathrm{~T}-123 \\ \text { Roanoke city, VA } & 4.01 & 125 \\ \text { Lunenburg County, VA } & 3.94 & 126 \\ \text { Fluvanna County, VA } & 3.70 & 127 \\ \text { Carroll County, VA } & 3.56 & 128 \\ \text { Dinwiddie County, VA } & 3.29 & 129 \\ \text { Richmond County, VA } & 3.26 & 130 \\ \text { Richmond city, VA } & 3.12 & 131 \\ \text { Middlesex County, VA } & 2.93 & 132 \\ \text { Petersburg city, VA } & 1.65 & 133 \\ & & \end{array}$

Note: The upward mobility measure used here is the percentage of low-income men who grew up in these counties who, in adulthood (their mid-30s), have a household income in the top $20 \%$ of the national income distribution for children born in the same year. Source: Authors' calculations using Opportunity Insights (2021) data. 
Table 2. Betas for U.S. Regression Models.

Adult Outcomes for Low-Income Men

Origin County Characteristic Mobility Income College Prison Marriage

Household Income

College Completion Rate

$\begin{array}{lllll}-0.168^{* * *} & -0.453^{* * *} & -0.265^{* * *} & 0.221^{* * *} & -0.615^{* * *} \\ 0.306^{* * *} & 0.283^{* * *} & 0.644^{* * *} & -0.161^{* * *} & 0.167^{* * *} \\ -0.515^{* * *} & -0.612^{* * *} & -0.231^{* * *} & 0.391^{* * *} & -0.575^{* * *} \\ 0.019 & -0.044 & -0.064 & -0.060 & -0.048^{*} \\ -0.052^{*} & -0.091^{* * *} & 0.014 & 0.313^{* * *} & -0.253^{* * *} \\ -0.057^{* *} & -0.032 & -0.010 & 0.062^{* *} & 0.016 \\ -0.052 & 0.078^{* *} & -0.086^{* *} & 0.053 & 0.091^{* * *} \\ 0.123^{* * *} & 0.122^{* * *} & 0.027 & -0.046^{* *} & 0.051^{* * *} \\ 0.134^{* * *} & 0.069^{* * *} & -0.001 & 0.084^{* * *} & -0.019 \\ 0.060^{* *} & 0.071^{* * *} & 0.069^{* * *} & -0.063^{* * *} & 0.049^{* * *} \\ 0.059^{* *} & -0.006 & -0.012 & -0.036 & 0.058^{* * *} \\ & & & & \\ 0.330 & 0.522 & 0.262 & 0.362 & 0.750 \\ 0.000 & 0.000 & 0.000 & 0.000 & 0.000\end{array}$

Single Parenthood Rate

Poverty Rate

Share Black

Math Scores

Employment Rate

Wage Growth

Job Growth

Job Density

Social Capital

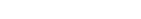

(2)

$\begin{array}{llllll}\text { Model r-square } & 0.330 & 0.522 & 0.262 & 0.362 & 0.750 \\ \text { Model significance } & 0.000 & 0.000 & 0.000 & 0.000 & 0.000\end{array}$

Note: $* p<.05, * * p<.01, * * * p<.001$.

Figure 1. Association between County Single Parenthood Rate and Mobility.

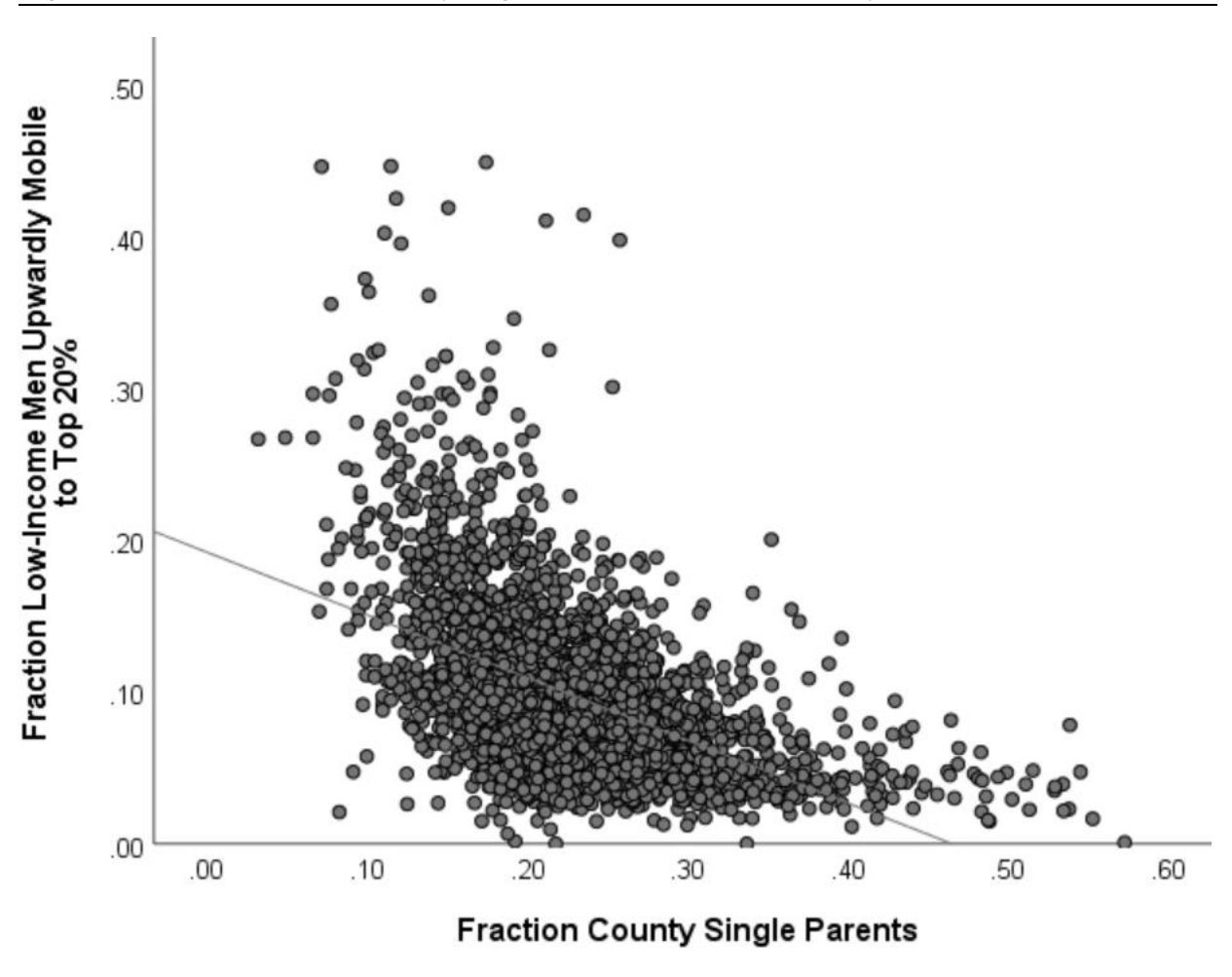

Note: $\mathrm{r}=-0.50 * * *$ 


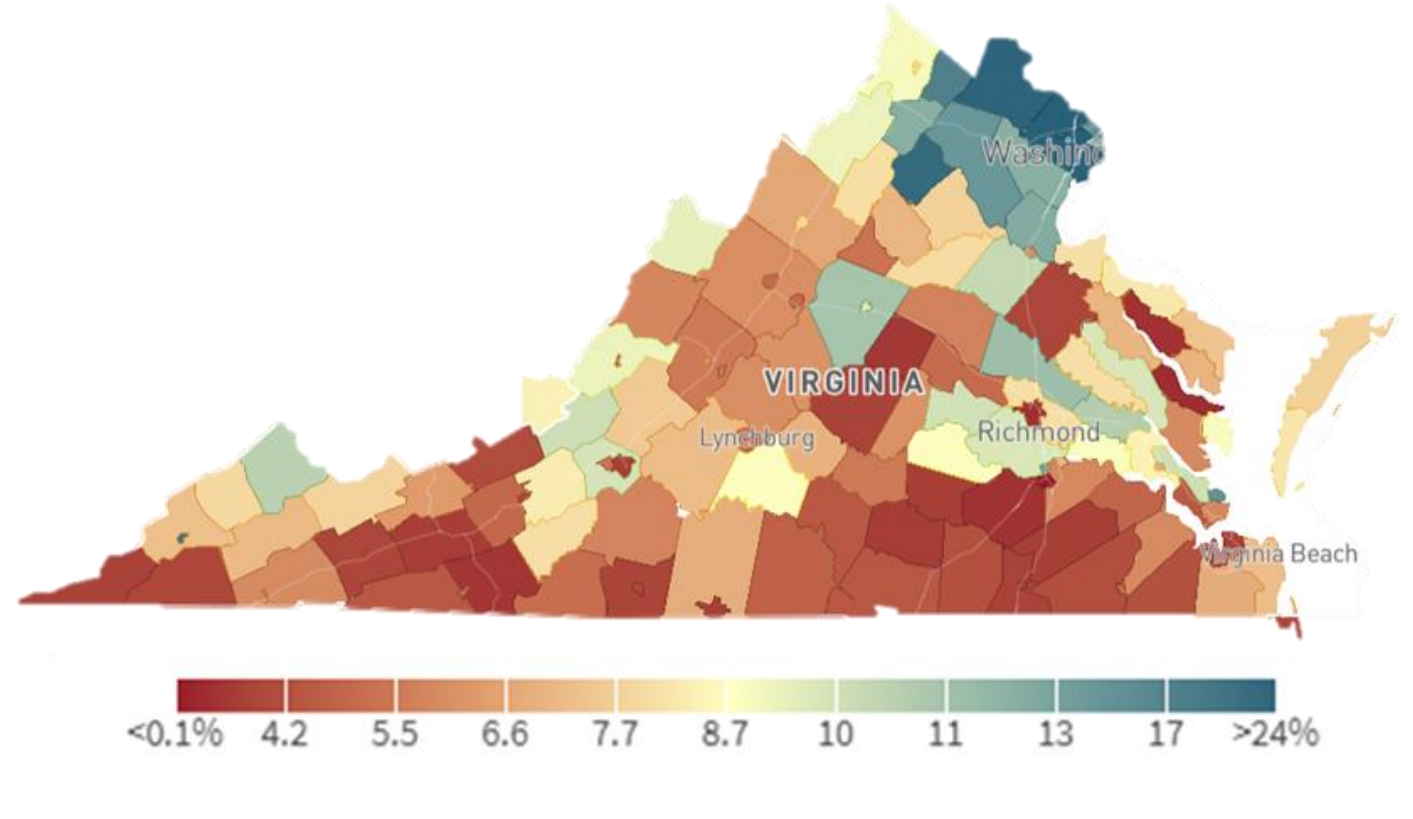

Note: The upward mobility measure used here is the percentage of low-income men who grew up in these counties who, when they reached adulthood (mid-30s), had a household income in the top 20\% of the national income distribution for children born in the same year.

Source: Opportunity Insights (2021). Map reprinted with permission.

Other measures of adult well-being showed similar inequalities. The percentage of low-income men who graduated college was as high as $48 \%$ in Falls Church City and as low as 0\% in places like Manassas Park City (see Table 3). As a state, Virginia appears to be below average compared to the rest of the country on college graduation for low-income men, given that $60 \%$ (78 out of 129 with available data) of the counties in the state had college completion rates below the national average. In a multiple linear regression model with all origin county characteristics included, county college completion rate proved to be the strongest predictor of college completion for low-income men (see Table 2). 
Table 3. Virginia Counties Ranked by College Graduation Rates for Low-Income Men

\begin{tabular}{|c|c|c|}
\hline VIRGINIA COUNTY & $\begin{array}{c}\% \\
\text { COLLEGE } \\
\text { GRADS }\end{array}$ & $\begin{array}{c}\text { VA } \\
\text { COLLEGE } \\
\text { RANK }\end{array}$ \\
\hline U.S. County Average & 13.74 & - \\
\hline Falls Church city, VA & 48.16 & 1 \\
\hline Fairfax city, VA & 42.46 & 2 \\
\hline Fairfax County, VA & 37.11 & 3 \\
\hline Poquoson city, VA & 34.51 & 4 \\
\hline Rappahannock County, VA & 34.07 & 5 \\
\hline Lexington city, VA & 28.90 & 6 \\
\hline Nelson County, VA & 28.80 & 7 \\
\hline York County, VA & 28.09 & 8 \\
\hline Alexandria city, VA & 27.71 & 9 \\
\hline Loudoun County, VA & 27.59 & 10 \\
\hline James City County, VA & 27.25 & 11 \\
\hline Radford city, VA & 26.14 & 12 \\
\hline Arlington County, VA & 23.37 & 13 \\
\hline Salem city, VA & 22.83 & 14 \\
\hline Franklin city, VA & 22.79 & 15 \\
\hline Albemarle County, VA & 21.60 & 16 \\
\hline Bland County, VA & 21.10 & 17 \\
\hline Colonial Heights city, VA & 20.88 & 18 \\
\hline Henrico County, VA & 20.84 & T-19 \\
\hline Roanoke County, VA & 20.84 & T-19 \\
\hline Buchanan County, VA & 20.21 & 21 \\
\hline Northampton County, VA & 19.57 & 22 \\
\hline Prince Edward County, VA & 19.47 & 23 \\
\hline Chesterfield County, VA & 19.43 & 24 \\
\hline Prince George County, VA & 18.72 & 25 \\
\hline Westmoreland County, VA & 17.99 & 26 \\
\hline Virginia Beach city, VA & 17.65 & 27 \\
\hline Staunton city, VA & 17.58 & 28 \\
\hline Charlottesville city, VA & 17.57 & 29 \\
\hline New Kent County, VA & 17.29 & 30 \\
\hline Bristol city, VA & 17.18 & 31 \\
\hline Prince William County, VA & 16.96 & 32 \\
\hline Accomack County, VA & 16.83 & 33 \\
\hline Washington County, VA & 16.59 & 34 \\
\hline Manassas city, VA & 16.50 & 35 \\
\hline Williamsburg city, VA & 16.41 & 36 \\
\hline Appomattox County, VA & 16.34 & 37 \\
\hline Tazewell County, VA & 15.74 & 38 \\
\hline Waynesboro city, VA & 15.66 & 39 \\
\hline Wythe County, VA & 15.65 & 40 \\
\hline Buckingham County, VA & 15.59 & 41 \\
\hline Rockingham County, VA & 15.22 & 42 \\
\hline Harrisonburg city, VA & 14.96 & 43 \\
\hline Winchester city, VA & 14.81 & 44 \\
\hline Hanover County, VA & 14.31 & 45 \\
\hline Covington city, VA & 14.27 & 46 \\
\hline
\end{tabular}


Hampton city, VA

Campbell County, VA

Clarke County, VA

Buena Vista city, VA

14.17

14.16

47

Galax city, VA

14.15

14.13

Chesapeake city, VA

Middlesex County, VA

Warren County, VA

13.64

Lee County, VA

13.17

Lynchburg city, VA

13.08

Newport News city, VA

13.06

Mecklenburg County, VA

12.93

Madison County, VA

12.92

Patrick County, VA

12.77

Wise County, VA

12.73

Isle of Wight County, VA

12.70

Bedford County, VA

Pittsylvania County, VA

Orange County, VA

Southampton County, VA

Greensville County, VA

Richmond County, VA

Richmond city, VA

Dickenson County, VA

Bath County, VA

Roanoke city, VA

Lancaster County, VA

Montgomery County, VA

Fauquier County, VA

King George County, VA

Danville city, VA

Fluvanna County, VA

Suffolk city, VA

Culpeper County, VA

Stafford County, VA

Lunenburg County, VA

Portsmouth city, VA

Franklin County, VA

Brunswick County, VA

Fredericksburg city, VA

Norfolk city, VA

Smyth County, VA

Henry County, VA

Northumberland County, VA

12.21

12.08

12.06

12.01

11.94

11.87

11.59

11.51

11.37

11.36

11.01

10.98

10.94

10.74

10.60

10.57

9.59

9.41

9.33

9.32

9.27

9.07

8.96

8.92

8.90

8.75

8.57

8.54

8.53

Petersburg city, VA

Norton city, VA

Louisa County, VA

Frederick County, VA

Giles County, VA

Amherst County, VA

Spotsylvania County, VA

Caroline County, VA

Hopewell city, VA

Rockbridge County, VA

Grayson County, VA

Powhatan County, VA 


\begin{tabular}{lcc} 
Charles City County, VA & 6.96 & 103 \\
Augusta County, VA & 6.87 & 104 \\
Dinwiddie County, VA & 6.75 & 105 \\
Nottoway County, VA & 6.11 & 106 \\
Page County, VA & 6.05 & 107 \\
Shenandoah County, VA & 5.93 & 108 \\
Alleghany County, VA & 5.43 & 109 \\
Greene County, VA & 5.35 & 110 \\
Scott County, VA & 5.19 & 111 \\
Amelia County, VA & 5.17 & 112 \\
Botetourt County, VA & 4.81 & 113 \\
Carroll County, VA & 4.56 & 114 \\
Charlotte County, VA & 4.01 & 115 \\
Halifax County, VA & 3.95 & 116 \\
Floyd County, VA & 3.74 & 117 \\
Emporia city, VA & 3.71 & 118 \\
Gloucester County, VA & 2.71 & 119 \\
Surry County, VA & 2.65 & 120 \\
Goochland County, VA & 2.64 & 121 \\
Cumberland County, VA & 2.23 & 122 \\
Martinsville city, VA & 1.69 & 123 \\
Sussex County, VA & 1.24 & 124 \\
Essex County, VA & 0.00 & $\mathrm{~T}-125$ \\
King William County, VA & 0.00 & $\mathrm{~T}-125$ \\
Pulaski County, VA & 0.00 & $\mathrm{~T}-125$ \\
Russell County, VA & 0.00 & $\mathrm{~T}-125$ \\
Manassas Park city, VA & 0.00 & $\mathrm{~T}-125$ \\
Craig County, VA & $\mathrm{n} / \mathrm{a}$ & - \\
Highland County, VA & $\mathrm{n} / \mathrm{a}$ & - \\
King and Queen County, VA & $\mathrm{n} / \mathrm{a}$ & - \\
Mathews County, VA & $\mathrm{n} / \mathrm{a}$ & \\
& & \\
\hline
\end{tabular}

Note: Counties with "n/a" entry did not have data available. The college graduation measure used here is the percentage of low-income men raised in these counties who had a bachelor's degree or higher by their mid-30s. Source: Authors' calculations using Opportunity Insights (2021) data.

The percentage of low-income men incarcerated in adulthood is as low as $0 \%$ in Highland County and as high as almost 14\% in Williamsburg City (see Table 4). As a state, Virginia does not appear to fare well compared to the rest of the country on incarceration rates for low-income men, given that 80\% (107 out of 133) of the counties in the state had incarceration rates above the national average. In a multiple linear regression model with all origin county characteristics included, county single parenthood rate proved to be the strongest predictor of low-income men's incarceration rate (see Table 2). Figure 3 illustrates the bivariate association between county single parenthood rate and low-income men's incarceration rate $(\mathrm{r}=0.52)$. 
Table 4. Virginia Counties Ranked by Incarceration Rates for Low-Income Men

\begin{tabular}{|c|c|c|}
\hline VIRGINIA COUNTY & $\begin{array}{c}\% \\
\text { INCARCERATED }\end{array}$ & $\begin{array}{c}\text { VA } \\
\text { INCARCERATION } \\
\text { RANK }\end{array}$ \\
\hline U.S. County Average & 3.93 & - \\
\hline Highland County, VA & 0.00 & 1 \\
\hline Bath County, VA & 0.64 & 2 \\
\hline Floyd County, VA & 1.76 & 3 \\
\hline Falls Church city, VA & 1.78 & 4 \\
\hline Fairfax city, VA & 2.02 & 5 \\
\hline Rappahannock County, VA & 2.09 & 6 \\
\hline Scott County, VA & 2.16 & 7 \\
\hline Fairfax County, VA & 2.32 & 8 \\
\hline Dickenson County, VA & 2.40 & 9 \\
\hline Poquoson city, VA & 2.49 & 10 \\
\hline Shenandoah County, VA & 2.63 & 11 \\
\hline Buchanan County, VA & 2.78 & 12 \\
\hline Goochland County, VA & 2.84 & 13 \\
\hline Nelson County, VA & 2.99 & 14 \\
\hline Buena Vista city, VA & 3.02 & 15 \\
\hline Warren County, VA & 3.10 & 16 \\
\hline Carroll County, VA & 3.32 & 17 \\
\hline Rockbridge County, VA & 3.35 & 18 \\
\hline Botetourt County, VA & 3.42 & 19 \\
\hline Lancaster County, VA & 3.48 & 20 \\
\hline Patrick County, VA & 3.55 & 21 \\
\hline Charlotte County, VA & 3.66 & 22 \\
\hline Amelia County, VA & 3.69 & 23 \\
\hline Rockingham County, VA & 3.72 & 24 \\
\hline Essex County, VA & 3.81 & 25 \\
\hline Lee County, VA & 3.90 & 26 \\
\hline Salem city, VA & 3.96 & 27 \\
\hline Bland County, VA & 4.07 & 28 \\
\hline Appomattox County, VA & 4.16 & 29 \\
\hline Roanoke County, VA & 4.23 & 30 \\
\hline Mathews County, VA & 4.25 & 31 \\
\hline Colonial Heights city, VA & 4.30 & 32 \\
\hline Cumberland County, VA & 4.32 & 33 \\
\hline Montgomery County, VA & 4.40 & 34 \\
\hline Grayson County, VA & 4.41 & 35 \\
\hline Alleghany County, VA & 4.46 & $\mathrm{~T}-36$ \\
\hline Tazewell County, VA & 4.46 & $\mathrm{~T}-36$ \\
\hline Washington County, VA & 4.50 & 38 \\
\hline Arlington County, VA & 4.52 & 39 \\
\hline Gloucester County, VA & 4.53 & 40 \\
\hline Albemarle County, VA & 4.60 & 41 \\
\hline Manassas Park city, VA & 4.61 & 42 \\
\hline Loudoun County, VA & 4.68 & 43 \\
\hline Hanover County, VA & 4.70 & 44 \\
\hline Smyth County, VA & 4.73 & 45 \\
\hline Bedford County, VA & 4.75 & 46 \\
\hline Bristol city, VA & 4.78 & 47 \\
\hline
\end{tabular}


Russell County, VA

4.85

Harrisonburg city, VA

Accomack County, VA

4.95

Galax city, VA

4.97

Alexandria city, VA

Powhatan County, VA

4.99

Northumberland County, VA

5.15

Amherst County, VA

5.25

Virginia Beach city, VA

5.27

Wise County, VA

Covington city, VA

King William County, VA

5.31

5.31

Prince William County, VA

5.37

Buckingham County, VA

Wythe County, VA

5.51

5.59

Augusta County, VA

5.70

Pulaski County, VA

New Kent County, VA

Campbell County, VA

Manassas city, VA

Spotsylvania County, VA

Lunenburg County, VA

Pittsylvania County, VA

Northampton County, VA

Dinwiddie County, VA

Nottoway County, VA

York County, VA

Norton city, VA

Winchester city, VA

Isle of Wight County, VA

Caroline County, VA

Middlesex County, VA

Madison County, VA

Chesterfield County, VA

Franklin County, VA

Page County, VA

Giles County, VA

Louisa County, VA

Frederick County, VA

Fauquier County, VA

Culpeper County, VA

Orange County, VA

Surry County, VA

Fluvanna County, VA

Clarke County, VA

Brunswick County, VA

Southampton County, VA

6.39

6.39

6.39

6.40

6.48

6.50

6.53

6.67

6.68

6.78

6.82

6.91

6.93

7.05

Prince George County, VA

7.06

Henrico County, VA

Waynesboro city, VA

7.22

Staunton city, VA

Stafford County, VA

Westmoreland County, VA

7.31

7.39

7.47

7.50

Craig County, VA

7.74

Halifax County, VA

7.86

Charles City County, VA

7.98

48

101

102

103 
Hampton city, VA

Sussex County, VA

Mecklenburg County, VA

Emporia city, VA

James City County, VA

Henry County, VA

Prince Edward County, VA

Radford city, VA

Hopewell city, VA

Roanoke city, VA

Greensville County, VA

Newport News city, VA

Greene County, VA

Richmond County, VA

Chesapeake city, VA

King and Queen County, VA

7.99

8.01

8.03

8.04

8.13

8.16

8.29

8.36

8.50

8.63

8.77

9.03

9.07

9.46

9.66

9.96

Fredericksburg city, VA

10.36

Danville city, VA

Lynchburg city, VA

Norfolk city, VA

11.04

11.33

King George County, VA

11.40

11.55

Suffolk city, VA

12.08

Martinsville city, VA

Petersburg city, VA

12.35

Lexington city, VA

Franklin city, VA

Portsmouth city, VA

Richmond city, VA

Charlottesville city, VA

Williamsburg city, VA

Note: The incarceration measure used here is the percentage of low-income men raised in these counties who were incarcerated in their mid-30s.

Source: Authors' calculations using Opportunity Insights (2021) data.

Figure 3. Association between County Single Parenthood Rate and Incarceration.

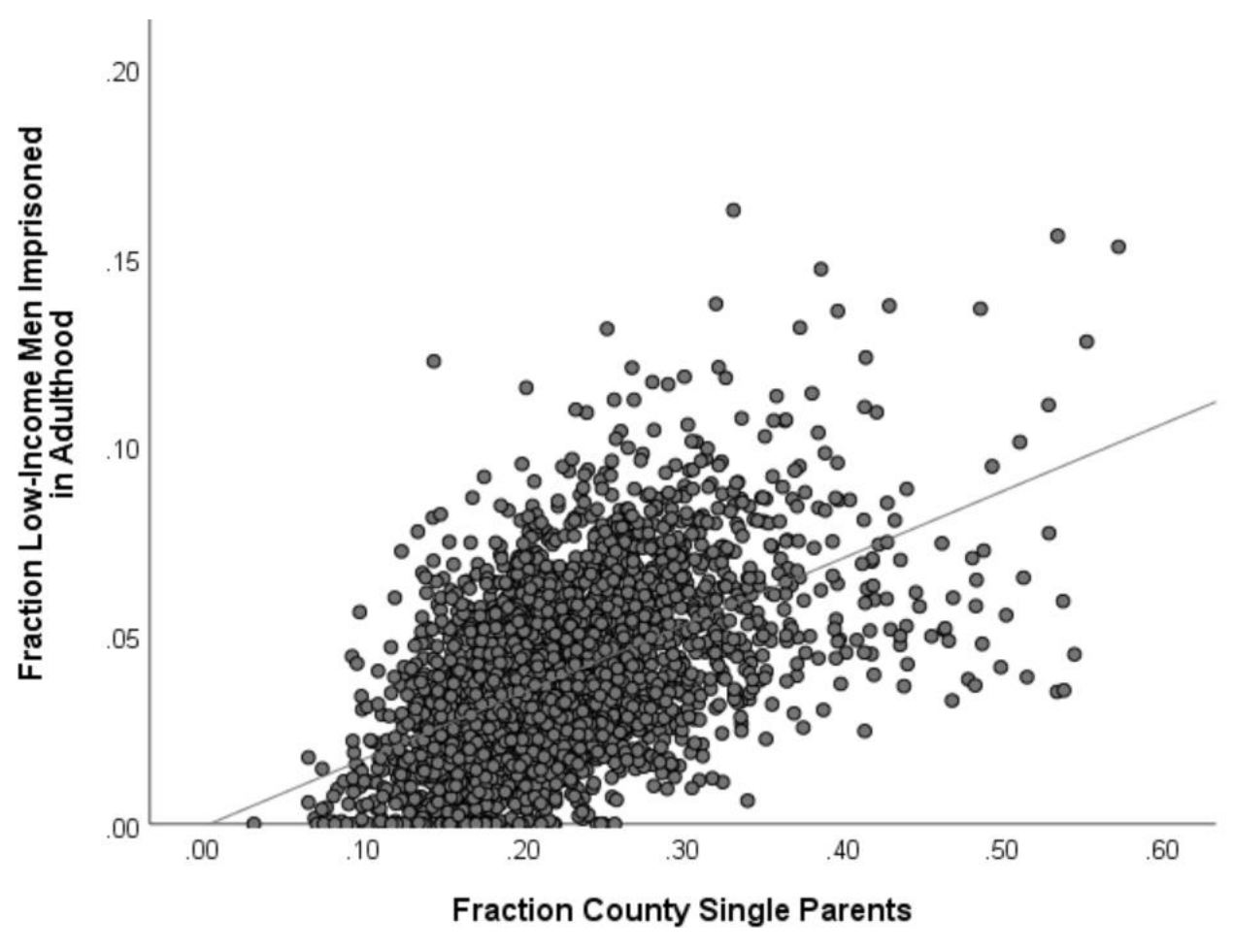

Note: $\mathrm{r}=0.52 * * *$ 
The average total household income of low-income men in adulthood is as high as $\$ 42,142$ in Falls Church City and as low as $\$ 18,317$ in Petersburg City (see Table 5). As a state, Virginia does not appear to fare well compared to the rest of the country on household income for low-income men, given that $89 \%$ (119 out of 133) of the counties in the state were below the national average on this measure. In a multiple linear regression model with all origin county characteristics included, county single parenthood rate proved to be the strongest predictor of low-income men's adult household income (see Table 2). Figure 4 illustrates the bivariate association between county single parenthood rate and low-income men's adult household income $(r=-0.65)$.

\begin{tabular}{|c|c|c|}
\hline VIRGINIA COUNTY & $\begin{array}{l}\text { AVERAGE } \\
\text { INCOME } \\
(\$)\end{array}$ & $\begin{array}{c}\text { VA } \\
\text { INCOME } \\
\text { RANK }\end{array}$ \\
\hline U.S. County Average & 33,567 & - \\
\hline Falls Church city, VA & 42,142 & 1 \\
\hline Rappahannock County, VA & 41,517 & 2 \\
\hline Fairfax County, VA & 40,664 & 3 \\
\hline Fairfax city, VA & 39,835 & 4 \\
\hline Loudoun County, VA & 38,828 & 5 \\
\hline Poquoson city, VA & 36,574 & 6 \\
\hline Buchanan County, VA & 35,766 & 7 \\
\hline New Kent County, VA & 35,279 & 8 \\
\hline Arlington County, VA & 35,104 & 9 \\
\hline Highland County, VA & 35,018 & 10 \\
\hline Manassas city, VA & 34,645 & 11 \\
\hline Clarke County, VA & 34,274 & 12 \\
\hline Essex County, VA & 33,927 & 13 \\
\hline King and Queen County, VA & 33,620 & 14 \\
\hline Bath County, VA & 33,503 & 15 \\
\hline Warren County, VA & 33,446 & 16 \\
\hline Botetourt County, VA & 33,389 & 17 \\
\hline Rockingham County, VA & 33,256 & 18 \\
\hline Dickenson County, VA & 33,255 & 19 \\
\hline Augusta County, VA & 33,146 & 20 \\
\hline Hanover County, VA & 33,053 & 21 \\
\hline Rockbridge County, VA & 32,763 & $\mathrm{~T}-22$ \\
\hline Stafford County, VA & 32,763 & $\mathrm{~T}-22$ \\
\hline Prince William County, VA & 32,756 & 24 \\
\hline Shenandoah County, VA & 32,739 & 25 \\
\hline Bland County, VA & 32,674 & 26 \\
\hline Roanoke County, VA & 32,577 & 27 \\
\hline King William County, VA & 32,338 & 28 \\
\hline York County, VA & 32,173 & 29 \\
\hline Russell County, VA & 32,163 & 30 \\
\hline Albemarle County, VA & 32,100 & 31 \\
\hline Manassas Park city, VA & 32,098 & 32 \\
\hline Northumberland County, VA & 31,910 & 33 \\
\hline Alexandria city, VA & 31,621 & 34 \\
\hline Powhatan County, VA & 31,543 & 35 \\
\hline Harrisonburg city, VA & 31,532 & 36 \\
\hline Frederick County, VA & 31,389 & 37 \\
\hline Middlesex County, VA & 31,305 & 38 \\
\hline Winchester city, VA & 31,205 & 39 \\
\hline Fauquier County, VA & 31,168 & 40 \\
\hline Tazewell County, VA & 31,154 & 41 \\
\hline Lexington city, VA & 30,935 & 42 \\
\hline Floyd County, VA & 30,931 & 43 \\
\hline Amherst County, VA & 30,839 & 44 \\
\hline Patrick County, VA & 30,775 & 45 \\
\hline Alleghany County, VA & 30,681 & 46 \\
\hline Bedford County, VA & 30,666 & 47 \\
\hline
\end{tabular}




\begin{tabular}{|c|c|c|}
\hline Mathews County, VA & 30,587 & 48 \\
\hline Nelson County, VA & 30,538 & 49 \\
\hline Colonial Heights city, VA & 30,395 & 50 \\
\hline Campbell County, VA & 30,081 & 51 \\
\hline Chesterfield County, VA & 30,058 & 52 \\
\hline Norton city, VA & 29,978 & 53 \\
\hline Scott County, VA & 29,928 & 54 \\
\hline Montgomery County, VA & 29,800 & 55 \\
\hline Buena Vista city, VA & 29,784 & 56 \\
\hline Salem city, VA & 29,726 & 57 \\
\hline Page County, VA & 29,620 & 58 \\
\hline Amelia County, VA & 29,583 & 59 \\
\hline Appomattox County, VA & 29,488 & 60 \\
\hline Covington city, VA & 29,387 & 61 \\
\hline Franklin County, VA & 29,281 & 62 \\
\hline Waynesboro city, VA & 29,162 & 63 \\
\hline Spotsylvania County, VA & 29,063 & 64 \\
\hline Virginia Beach city, VA & 28,980 & 65 \\
\hline Craig County, VA & 28,872 & 66 \\
\hline Accomack County, VA & 28,871 & 67 \\
\hline Madison County, VA & 28,865 & 68 \\
\hline Staunton city, VA & 28,730 & 69 \\
\hline Wythe County, VA & 28,727 & 70 \\
\hline Lancaster County, VA & 28,698 & 71 \\
\hline Prince George County, VA & 28,459 & 72 \\
\hline Charles City County, VA & 28,360 & 73 \\
\hline Gloucester County, VA & 28,285 & 74 \\
\hline Culpeper County, VA & 28,192 & 75 \\
\hline Wise County, VA & 28,124 & 76 \\
\hline Richmond County, VA & 28,015 & 77 \\
\hline Giles County, VA & 27,964 & 78 \\
\hline James City County, VA & 27,898 & 79 \\
\hline Fluvanna County, VA & 27,868 & 80 \\
\hline Pittsylvania County, VA & 27,858 & 81 \\
\hline Grayson County, VA & 27,806 & 82 \\
\hline Westmoreland County, VA & 27,780 & 83 \\
\hline Lee County, VA & 27,755 & 84 \\
\hline King George County, VA & 27,705 & 85 \\
\hline Surry County, VA & 27,699 & 86 \\
\hline Orange County, VA & 27,644 & 87 \\
\hline Isle of Wight County, VA & 27,617 & 88 \\
\hline Washington County, VA & 27,512 & 89 \\
\hline Bristol city, VA & 27,495 & 90 \\
\hline Henrico County, VA & 27,493 & 91 \\
\hline Greene County, VA & 27,154 & 92 \\
\hline Carroll County, VA & 26,997 & 93 \\
\hline Southampton County, VA & 26,889 & 94 \\
\hline Smyth County, VA & 26,747 & 95 \\
\hline Sussex County, VA & 26,689 & 96 \\
\hline Chesapeake city, VA & 26,663 & 97 \\
\hline Fredericksburg city, VA & 26,626 & 98 \\
\hline Hampton city, VA & 26,477 & 99 \\
\hline Nottoway County, VA & 26,438 & 100 \\
\hline Galax city, VA & 26,358 & 101 \\
\hline Goochland County, VA & 26,312 & 102 \\
\hline Henry County, VA & 26,251 & 103 \\
\hline
\end{tabular}


Franklin city, VA

Charlotte County, VA

Pulaski County, VA

$26,127 \quad 104$

26,096 T-105

Northampton County, VA

26,096 T-105

Buckingham County, VA

26,094 107

Caroline County, VA

Prince Edward County, VA

$26,069-108$

Lunenburg County, VA

$25,956 \quad 109$

Louisa County, VA

$25,886-110$

Hopewell city, VA

Brunswick County, VA

$25,803 \quad 111$

$25,645 \quad 112$

Cumberland County, VA

$25,387 \quad 113$

Newport News city, VA

25,377

25,282

25,047

Halifax County, VA

Mecklenburg County, VA

25,038

24,843

Lynchburg city, VA

Charlottesville city, VA

24,479

24,368

Williamsburg city, VA

24,293

Dinwiddie County, VA

24,239

Suffolk city, VA

Norfolk city, VA

24,162

22,980

Roanoke city, VA

Portsmouth city, VA

Radford city, VA

22,907

22,604

22,311

22,071

21,543

Greensville County, VA

19,642

19,559

Emporia city, VA

Richmond city, VA

Petersburg city, VA

18,381

18,317

Note: The income measure used here is the average annual total household income of low-income men raised in these counties when they reach their mid30 s.

Source: Authors' calculations using Opportunity Insights (2021) data.

Figure 4. Association between County Single Parenthood Rate and Income.

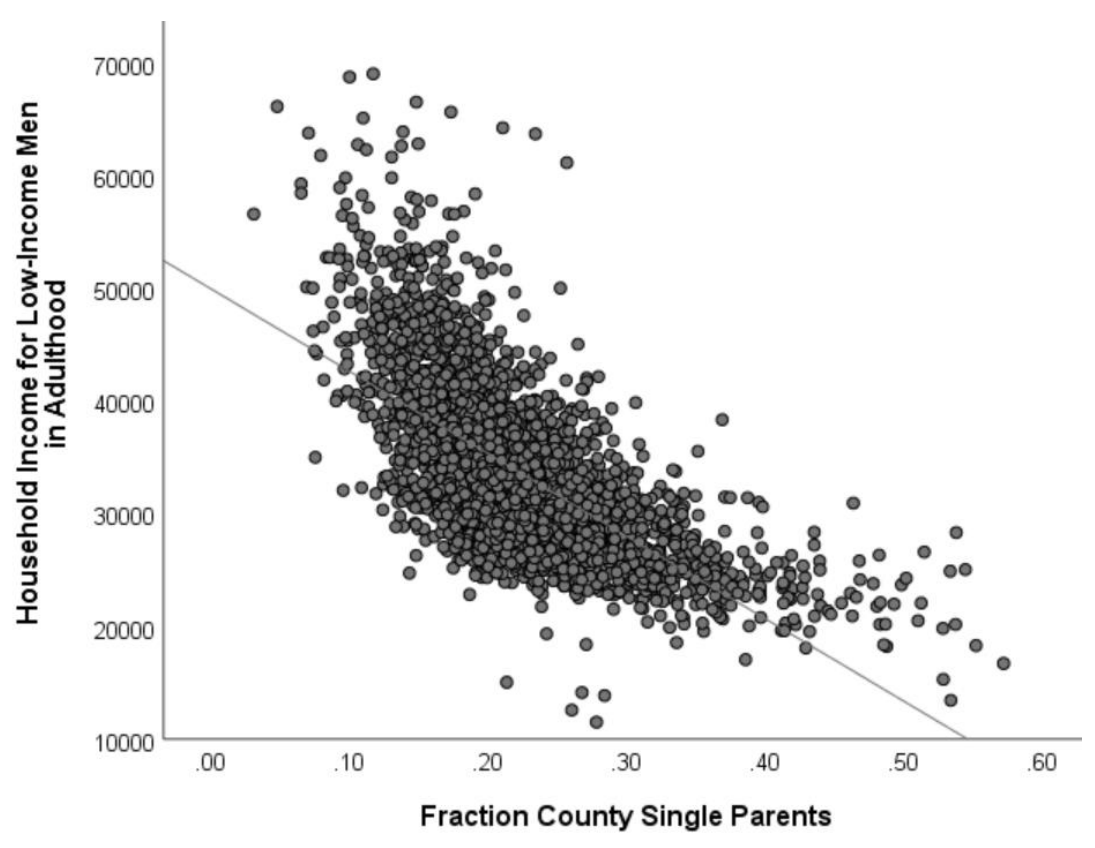

Note: $\mathrm{r}=-0.65^{* * *}$ 
The average marriage rate of low-income men in adulthood is as high as $55 \%$ in Bath County and as low as less than $15 \%$ in Petersburg City (see Table 6). As a state, Virginia does not appear to fare well compared to the rest of the country on marriage rates for low-income men, given that 77\% (102 out of 133) of the counties in the state had marriage rates below the national average. In a multiple linear regression model with all origin county characteristics included, county household income and single parenthood rate proved to be the strongest predictors of low-income men's adult marriage rate (see Table 2). Figure 5 illustrates the bivariate association between county single parenthood rate and low-income men's adult marriage rate $(r=-0.72)$.

\begin{tabular}{|c|c|c|}
\hline VIRGINIA COUNTY & $\begin{array}{c}\% \\
\text { MARRIED }\end{array}$ & $\begin{array}{c}\text { VA } \\
\text { MARRIAGE } \\
\text { RANK }\end{array}$ \\
\hline U.S. County Average & 39.87 & - \\
\hline Bath County, VA & 55.32 & 1 \\
\hline Dickenson County, VA & 52.02 & 2 \\
\hline Highland County, VA & 51.40 & 3 \\
\hline Buchanan County, VA & 51.09 & 4 \\
\hline Russell County, VA & 47.78 & 5 \\
\hline Tazewell County, VA & 47.21 & 6 \\
\hline Bland County, VA & 47.09 & 7 \\
\hline Craig County, VA & 46.74 & 8 \\
\hline Augusta County, VA & 46.37 & 9 \\
\hline Rappahannock County, VA & 45.43 & 10 \\
\hline Buena Vista city, VA & 44.00 & 11 \\
\hline Lee County, VA & 43.75 & 12 \\
\hline Grayson County, VA & 43.60 & 13 \\
\hline Scott County, VA & 43.47 & 14 \\
\hline Rockbridge County, VA & 43.25 & 15 \\
\hline Wythe County, VA & 43.18 & 16 \\
\hline Wise County, VA & 42.92 & 17 \\
\hline Botetourt County, VA & 42.90 & 18 \\
\hline Bristol city, VA & 42.14 & 19 \\
\hline Patrick County, VA & 41.91 & 20 \\
\hline Rockingham County, VA & 41.82 & 21 \\
\hline Carroll County, VA & 41.73 & 22 \\
\hline Warren County, VA & 41.37 & 23 \\
\hline Norton city, VA & 41.16 & 24 \\
\hline Franklin County, VA & 41.15 & 25 \\
\hline Roanoke County, VA & 40.97 & 26 \\
\hline Powhatan County, VA & 40.85 & 27 \\
\hline Madison County, VA & 40.49 & 28 \\
\hline Covington city, VA & 40.28 & 29 \\
\hline Alleghany County, VA & 39.97 & 30 \\
\hline Page County, VA & 39.88 & 31 \\
\hline Bedford County, VA & 39.66 & 32 \\
\hline Washington County, VA & 39.00 & 33 \\
\hline Shenandoah County, VA & 38.97 & 34 \\
\hline Nelson County, VA & 38.95 & 35 \\
\hline Appomattox County, VA & 38.94 & 36 \\
\hline Northumberland County, VA & 38.89 & 37 \\
\hline Campbell County, VA & 38.78 & 38 \\
\hline Poquoson city, VA & 38.48 & 39 \\
\hline Harrisonburg city, VA & 38.11 & 40 \\
\hline Salem city, VA & 37.90 & 41 \\
\hline Montgomery County, VA & 37.83 & 42 \\
\hline Smyth County, VA & 37.56 & 43 \\
\hline Amherst County, VA & 37.54 & 44 \\
\hline Floyd County, VA & 37.38 & $\mathrm{~T}-45$ \\
\hline Staunton city, VA & 37.38 & $\mathrm{~T}-45$ \\
\hline Giles County, VA & 37.27 & 47 \\
\hline
\end{tabular}




\begin{tabular}{|c|c|c|}
\hline Charlotte County, VA & 36.76 & 48 \\
\hline Fairfax city, VA & 36.65 & 49 \\
\hline New Kent County, VA & 36.38 & 50 \\
\hline Mathews County, VA & 36.35 & 51 \\
\hline Pulaski County, VA & 36.08 & 52 \\
\hline Fairfax County, VA & 36.07 & 53 \\
\hline Gloucester County, VA & 35.99 & 54 \\
\hline Fauquier County, VA & 35.92 & 55 \\
\hline Frederick County, VA & 35.90 & 56 \\
\hline Clarke County, VA & 35.30 & 57 \\
\hline Loudoun County, VA & 35.29 & 58 \\
\hline Albemarle County, VA & 34.83 & 59 \\
\hline Galax city, VA & 34.82 & 60 \\
\hline Greene County, VA & 34.36 & T-61 \\
\hline Middlesex County, VA & 34.36 & T-61 \\
\hline Cumberland County, VA & 34.27 & 63 \\
\hline Stafford County, VA & 33.86 & 64 \\
\hline Manassas city, VA & 33.65 & 65 \\
\hline King George County, VA & 33.62 & $\mathrm{~T}-66$ \\
\hline Winchester city, VA & 33.62 & $\mathrm{~T}-66$ \\
\hline Henry County, VA & 33.59 & 68 \\
\hline Culpeper County, VA & 33.37 & 69 \\
\hline Pittsylvania County, VA & 33.05 & 70 \\
\hline Hanover County, VA & 33.04 & 71 \\
\hline Colonial Heights city, VA & 33.01 & 72 \\
\hline Lexington city, VA & 32.98 & 73 \\
\hline Waynesboro city, VA & 32.67 & 74 \\
\hline King William County, VA & 32.43 & 75 \\
\hline Arlington County, VA & 31.98 & 76 \\
\hline Louisa County, VA & 31.88 & 77 \\
\hline Orange County, VA & 31.77 & 78 \\
\hline York County, VA & 31.68 & 79 \\
\hline Accomack County, VA & 31.61 & 80 \\
\hline Falls Church city, VA & 31.60 & 81 \\
\hline Fluvanna County, VA & 31.48 & 82 \\
\hline Lunenburg County, VA & 31.37 & 83 \\
\hline King and Queen County, VA & 31.28 & 84 \\
\hline Spotsylvania County, VA & 30.91 & 85 \\
\hline Prince William County, VA & 30.61 & 86 \\
\hline Radford city, VA & 30.39 & 87 \\
\hline Chesterfield County, VA & 30.13 & 88 \\
\hline Prince George County, VA & 30.07 & 89 \\
\hline Prince Edward County, VA & 29.96 & 90 \\
\hline Buckingham County, VA & 29.94 & 91 \\
\hline Manassas Park city, VA & 29.70 & 92 \\
\hline Amelia County, VA & 29.51 & 93 \\
\hline Virginia Beach city, VA & 29.23 & 94 \\
\hline Westmoreland County, VA & 28.99 & 95 \\
\hline Nottoway County, VA & 28.84 & $\mathrm{~T}-96$ \\
\hline Lynchburg city, VA & 28.84 & $\mathrm{~T}-96$ \\
\hline Northampton County, VA & 28.48 & 98 \\
\hline Lancaster County, VA & 28.38 & 99 \\
\hline James City County, VA & 28.10 & 100 \\
\hline Surry County, VA & 28.01 & 101 \\
\hline Richmond County, VA & 27.69 & 102 \\
\hline Halifax County, VA & 27.62 & 103 \\
\hline
\end{tabular}




$\begin{array}{lll}\text { Mecklenburg County, VA } & 27.39 & 104 \\ \text { Isle of Wight County, VA } & 27.36 & 105 \\ \text { Alexandria city, VA } & 27.01 & 106 \\ \text { Brunswick County, VA } & 26.64 & 107 \\ \text { Essex County, VA } & 26.51 & 108 \\ \text { Goochland County, VA } & 26.30 & 109 \\ \text { Roanoke city, VA } & 25.97 & 110 \\ \text { Hopewell city, VA } & 25.65 & 111 \\ \text { Fredericksburg city, VA } & 25.52 & 112 \\ \text { Chesapeake city, VA } & 25.51 & 113 \\ \text { Sussex County, VA } & 24.91 & 114 \\ \text { Hampton city, VA } & 24.90 & 115 \\ \text { Henrico County, VA } & 24.67 & 116 \\ \text { Caroline County, VA } & 24.61 & 117 \\ \text { Charlottesville city, VA } & 23.96 & 118 \\ \text { Newport News city, VA } & 23.60 & 119 \\ \text { Franklin city, VA } & 23.51 & 120 \\ \text { Danville city, VA } & 23.33 & 121 \\ \text { Southampton County, VA } & 22.99 & 122 \\ \text { Charles City County, VA } & 22.98 & 123 \\ \text { Williamsburg city, VA } & 22.15 & 124 \\ \text { Norfolk city, VA } & 21.10 & 125 \\ \text { Suffolk city, VA } & 20.80 & 126 \\ \text { Martinsville city, VA } & 20.70 & 127 \\ \text { Portsmouth city, VA } & 20.38 & 128 \\ \text { Greensville County, VA } & 19.91 & 129 \\ \text { Dinwiddie County, VA } & 18.55 & 130 \\ \text { Emporia city, VA } & 17.41 & 131 \\ \text { Richmond city, VA } & 14.79 & 132 \\ \text { Petersburg city, VA } & 14.73 & 133\end{array}$

Note: The marriage measure used here is the percentage of low-income men raised in these counties who were married in their mid-30s.

Source: Authors' calculations using Opportunity Insights (2021) data.

Figure 5. Association between County Single Parenthood Rate and Marriage.

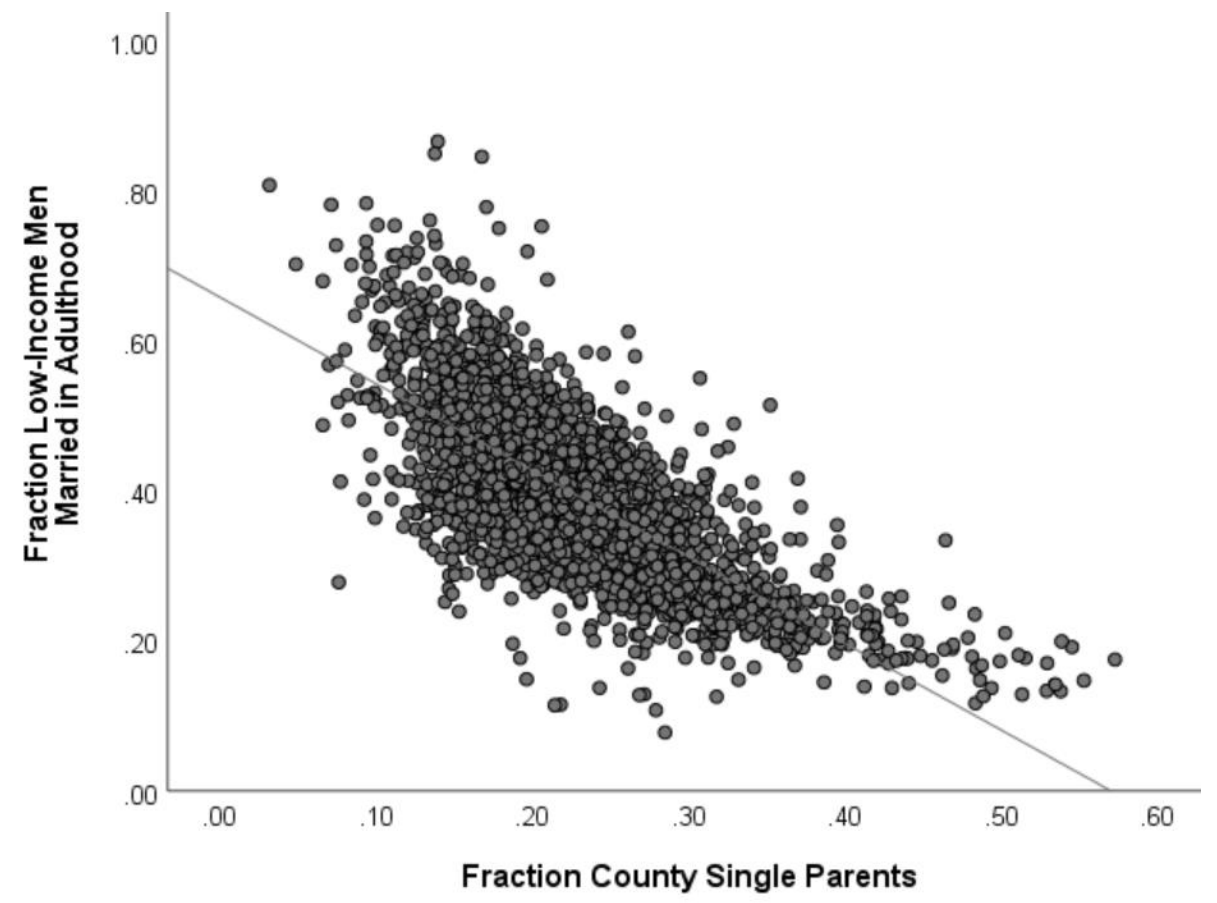

Note: $\mathrm{r}=-0.72^{* * *}$

There was also significant inequality between counties in county characteristics. Table 8 , for instance, demonstrates wide gaps across the state in county-level college completion (72 percentage point gap), poverty 
(41 percentage point gap), single parenthood (53 percentage point gap), household income (\$101,865 gap), and racial segregation (79 percentage point gap).

\section{Inequality of Place and Violence}

Figure 6 demonstrates the visible association between clusters of homicides and concentrated disadvantage across the city of Richmond, VA. The largest homicide clusters are in the easternmost portion of the city. This area also has high levels of poverty and single parenthood, low household income and college completion, and poor adult outcomes for low-income men (in terms of upward mobility, incarceration, and marriage). Additionally, this area has high concentrations of Black residents, reflecting racial segregation. In the much more advantaged westernmost portions of the city, there are notably no gun homicides.
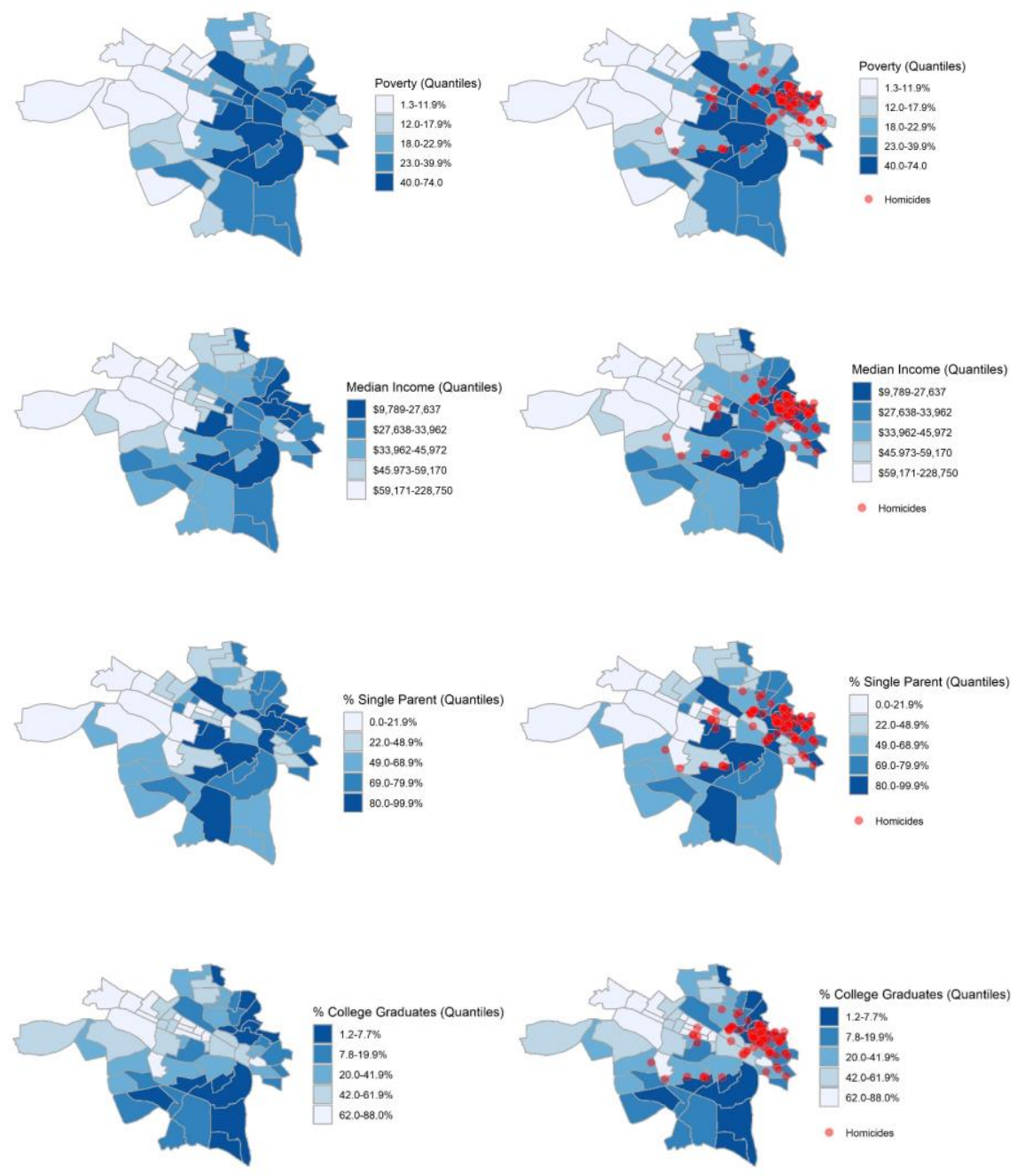

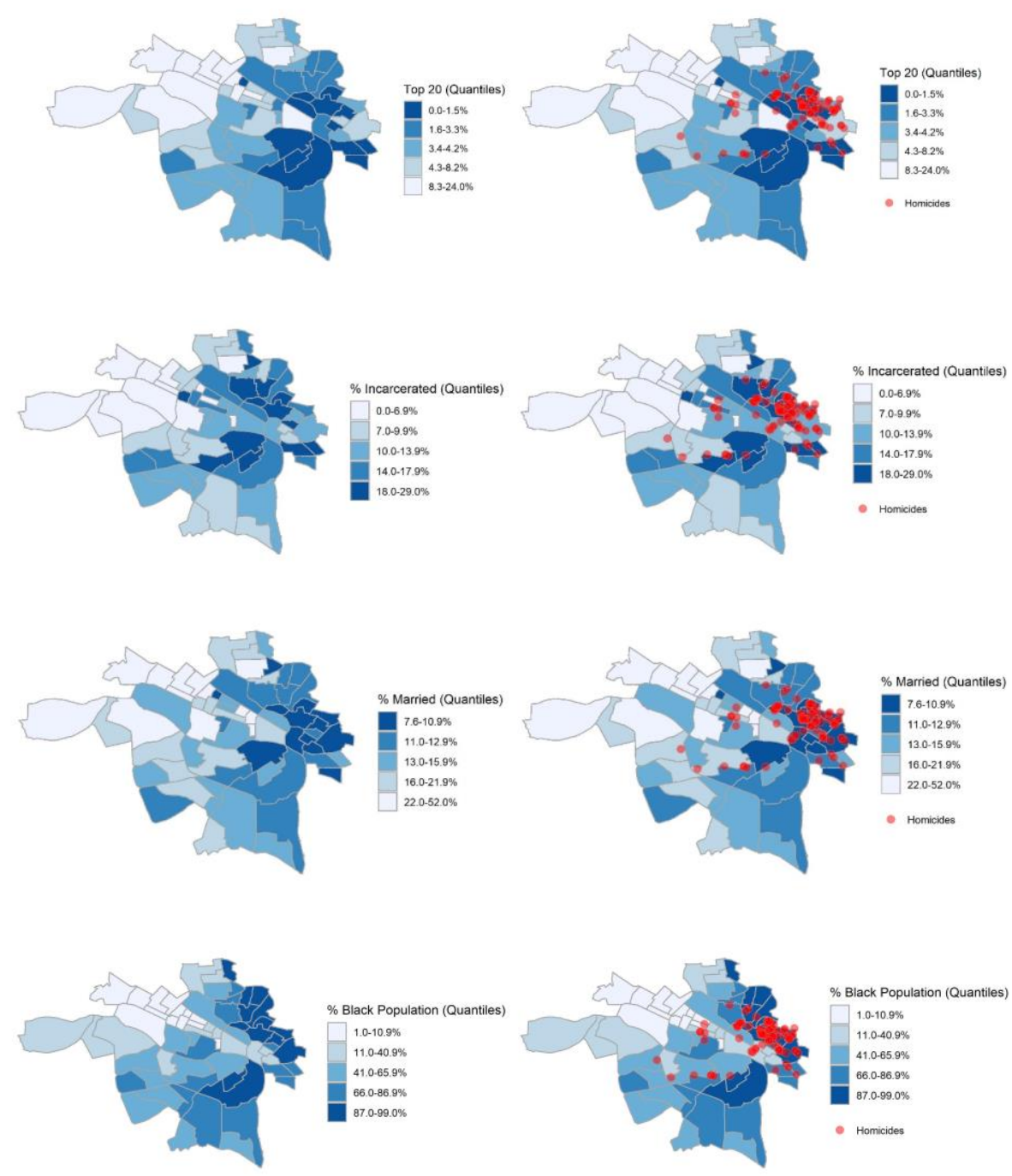

Source: Authors' calculations using LexisNexis (2020) and Opportunity Insights (2021) data.

\section{Economic Cost of Child Poverty}

Growing up poor reduces a person's earnings as an adult. Since Virginia's share of total GDP was $2.66 \%$ in 2015, we assigned 2.66\% of the cost of reduced earnings from McLaughlin \& Rank (2018) to find Virginia's share of this cost, which is $\$ 7.81$ billion (see Table 7). Child poverty also leads to increased street crime when poor children become adults. The state of Virginia was responsible for $1.32 \%$ of U.S. violent crime in 2015, so we assigned $1.32 \%$ of the cost of increased street crime from McLaughlin \& Rank (2018) to find Virginia's share of this cost, which is $\$ 2.65$ billion.

Virginia was also responsible for $2.08 \%$ of U.S. health expenditures, $2.61 \%$ of the U.S. homeless population, and $2.06 \%$ of U.S. child maltreatment referrals in 2015 , so we use those percentages to adjust the figures from McLaughlin \& Rank (2018) to obtain costs of $\$ 3.99, \$ 1.20$, and $\$ 0.83$ billion for increased healthcare costs, homelessness, and child maltreatment, respectively. Finally, Virginia held $2.89 \%$ of state prisoners in the U.S. during 2015, so we assign $2.89 \%$ of the corrections costs and social costs related to incarceration from McLaughlin \& Rank (2018), which yields corrections costs of $\$ 3.54$ billion and social incarceration costs of $\$ 2.40$ billion for Virginia. 
Summing these costs yielded an aggregate cost of child poverty of $\$ 22.43$ billion for Virginia in 2015 . When we adjusted this figure to 2019 dollars using the inflation calculator provided by the U.S. Bureau of Labor Statistics (2020), the resulting cost was $\$ 24.37$ billion, or about 42\% of Virginia's operating expenses in 2019 (see Virginia Department of Planning and Budget 2020).

Table 7. Estimating the Economic Costs of Child Poverty in the State of Virginia.

\begin{tabular}{|c|c|c|c|}
\hline U.S. cost description & $\begin{array}{l}\text { U.S. cost } \\
\text { (in billions) }\end{array}$ & $\begin{array}{l}\text { Virginia's } \\
\text { share }\end{array}$ & $\begin{array}{l}\text { Virginia cost } \\
\text { (in billions) }\end{array}$ \\
\hline Reduced earnings & $\$ 294.0$ & $2.66 \%$ & $\$ 7.81$ \\
\hline $\begin{array}{l}\text { Increased victimization costs of } \\
\text { street crime }\end{array}$ & $\$ 200.6$ & $1.32 \%$ & $\$ 2.65$ \\
\hline Increased health costs & $\$ 192.1$ & $2.08 \%$ & $\$ 3.99$ \\
\hline $\begin{array}{l}\text { Increased corrections and crime } \\
\text { deterrence costs }\end{array}$ & $\$ 122.5$ & $2.89 \%$ & $\$ 3.54$ \\
\hline Increased child homelessness costs & $\$ 96.9$ & $1.24 \%$ & $\$ 1.20$ \\
\hline $\begin{array}{l}\text { Increased social costs of } \\
\text { incarceration }\end{array}$ & $\$ 83.2$ & $2.89 \%$ & $\$ 2.40$ \\
\hline Increased child maltreatment costs & $\$ 40.5$ & $2.06 \%$ & $\$ 0.83$ \\
\hline Total cost of child poverty in 2015 & $\$ 1029.8$ & - & $\$ 22.43$ \\
\hline $\begin{array}{l}\text { Total cost of child poverty in } 2019 \\
\quad \text { (inflation adjusted) }\end{array}$ & $\$ 1118.8$ & - & $\$ 24.37$ \\
\hline
\end{tabular}

Source: Authors' calculations based using data from McLaughlin \& Rank (2018).

Table 8. Summary of Inequalities in Virginia County Characteristics

\begin{tabular}{lccc}
\hline & VA Average & Smallest & Largest \\
\hline & & & \\
\% college graduates & $25.5 \%$ & $8.5 \%$ & $80.2 \%$ \\
Poverty rate & $14.9 \%$ & $2.7 \%$ & $43.8 \%$ \\
Single parenthood rate & $33.7 \%$ & $14.7 \%$ & $67.2 \%$ \\
Median household income & $\$ 54,579$ & $\$ 25,676$ & $\$ 127,541$ \\
Fraction Black & $19.6 \%$ & $<1 \%$ & $79.7 \%$ \\
\end{tabular}

Source: Authors' calculations using Opportunity Insights (2021) data.

\section{Discussion \& Conclusion}

Previous research suggests that there is significant inequality of place in the U.S., and our results align with these previous findings. There were large gaps between counties in their characteristics, such as college completion (72 percentage point gap), poverty (41 percentage point gap), single parenthood (53 percentage point gap), household income ( $\$ 101,865$ gap), and racial segregation (79 percentage point gap) (refer back to Table 8). In terms of lowincome men's adult outcomes, there were major inequalities between counties in upward mobility (high of $21 \%$ and low of less than $2 \%$ ), college completion ( $48 \%$ versus $0 \%$ ), incarceration ( $0 \%$ versus $14 \%$ ), household income (\$42,142 versus $\$ 18,317)$, and marriage (55\% versus less than 15\%) (refer back to Tables 1 and 3-6).

Previous research suggests that neighborhood- and community-level characteristics are strongly associated with these outcomes, and our results align with these previous findings. Single parenthood was particularly impactful - despite the presence of several control variables in the multiple linear regression models, single parenthood still had the largest Beta value in the upward mobility, household income, and incarceration models, 
and was almost as impactful as household income in predicting marriage. ${ }^{28}$ This is consistent with the seminal work of Chetty and his colleagues (2014), which found single parenthood to be the variable most strongly associated with mobility across U.S. commuting zones. Other county level characteristics that were particularly impactful in our regression models were college completion (predicting upward mobility and college completion), household income (household income and marriage), and racial segregation (incarceration) (refer back to Table 2).

Previous research suggests that violence tends to erupt in areas of concentrated disadvantage in the U.S., findings which align with our mapping of homicides and concentrated disadvantage in Virginia's capital city of Richmond. There was visible overlap between clusters of homicides and high levels of poverty, single parenthood, and racial segregation, low household income and college completion, and poor adult outcomes for low-income men (upward mobility, incarceration, and marriage). There were no homicides in the much more advantaged westernmost portions of the city (refer back to Figure 6).

As previous research also suggests, the cost of childhood poverty in Virginia is significant. According to our analysis, allowing child poverty to persist costs the state billions of dollars in the resulting decrease in potential adult earnings and increase in costs related to crime/incarceration, health, homelessness, and maltreatment (refer back to Table 7).

In summary, (a) major inequalities of place are apparent in the state of Virginia, (b) these inequalities likely have a significant influence on the unequal life chances of children raised in the state, (c) these inequalities are likely associated with one's likelihood of violent crime involvement and victimization, and (d) economic deprivation is economically costly to the larger society, not just disadvantaged individuals themselves.

\section{Author Bios}

Lawrence M. Eppard is a faculty member at Shippensburg University, director of the Connors Forum for a Healthy Democracy, and host of the Utterly Moderate Podcast, which is distributed by 77 newspapers around the United States.

Erik Nelson is a faculty member at Brigham Young University.

Michael McLaughlin is a faculty member at Illinois Wesleyan University.

\footnotetext{
${ }^{28}$ There are a variety of reasonable responses one might have to our findings concerning single parenthood, including (a) whether this blames single parents for their children's outcomes, or (b) whether this could be a spurious relationship. On the first question, our research does not offer much clarity. We can speculate based on previous research, however, that while single parenthood is in part a personal decision within the control of those involved, it is also in part a result of forces outside of one's control. The difficulties of forming and maintaining relationships amidst concentrated disadvantage (economic insecurity, unemployment, failing institutions, crime, mass incarceration, etc.), for instance, are well-documented-for just a few examples, see McLanahan \& Sandefur 1994, Hays 2003, Edin \& Kefalas 2005, and Hertz 2006. On the second question, there are a variety of unmeasured dimensions of disadvantage that could be confounding variables. The ones we did include in our models (such as poverty), however, did not change the fact that single parenthood was an important factor. If poverty was simply 'lurking in the background' and boosting the perceived impact of single parenthood on children's outcomes when measured in a bivariate manner, then the impact of single parenthood should have dropped considerably or been statistically insignificant in the multivariate models, but that did not happen. Furthermore, previous research supports the notion that single parenthood is disadvantaging independent of other variables that might be related, such as income and education (Hymowitz 2006; Chetty et. al. 2014; Kearney \& Levine 2017). Kearney and Levine (2017), for instance, found a marriage premium at various ages and educational attainment levels. And Chetty and his colleagues (2014) found that not only were community single parenthood rates strongly correlated with upward mobility for all low-income children, but they were also strongly correlated with upward mobility for low-income children who themselves grew up in married-parent households.
} 
Theresa Ward is an undergraduate student at Shippensburg University.

\section{Bibliography}

Aaronson, D. (1998). Using Sibling Data to Estimate the Impact of Neighborhoods on Children's Educational Outcomes. Journal of Human Resources 33(4): 915-946. https://doi.org/10.2307/146403

Allard, S. W., Small, M. L. (2013). Reconsidering the Urban Disadvantaged: The Role of Systems, Institutions, and Organizations. The Annals of the American Academy of Political and Social Science 647(1): 6-20.

The Annie E. Casey Foundation (AECF). (2021). Children in Poverty (100 Percent Poverty) in Virginia. https://datacenter.kidscount.org/data/tables/43-children-in-poverty-100percent-poverty\#detailed/2/48/false/1729/any/321,322.

Bischoff, K., Reardon, S.F. (2014). Residential Segregation by Income, 1970-2009. In J. Logan (Ed) Diversity and Disparities: America Enters a New Century (pp. 208-233). The Russell Sage Foundation.

Blau, F. D., Kahn, 1. M.. (2017). The Gender Wage Gap: Extent, Trends, and Explanations. Journal of Economic Literature 55(3): 789-865. http://doi.org/10.1257/jel.20160995

Brady, S. S.,Gorman-Smith, D., Henry, D. B., Tolan, P. H. (2008). Adaptive Coping Reduces the Impact of Community Violence Exposure on Violent Behavior among African American and Latino Male Adolescents. Journal of Abnormal Child Psychology. 36(1): 105-115. https://doi.org/10.1007/s10802007-9164-X

Bronzaft, A. L., McCarthy, D. P. (1975). The Effect of Elevated Train Noise on Reading Ability. Environmental Behavior 7(4): 517-527. https://doi.org/10.1177/001391657500700406

Burdick-Will, J., Ludwig, J., Raudenbush, S. W., Sampson, R. J., Sanbonmatsu, L., \& Sharkey, P. (2011). Converging evidence for neighborhood effects on children's test scores: An experimental, quasiexperimental, and observational comparison. In Whither Opportunity?: Rising Inequality, Schools, and Children's Life Chances (pp. 255-276). Russell Sage Foundation.

Chetty, R. (2014, April 1). Improving Opportunities for Economic Mobility in the United States. Testimony for the Budget Committee of the United States Senate.

https://www.budget.senate.gov/imo/media/doc/Chetty\%20mobility\%20testimony.pdf.

Chetty, R., Hendren, N., Kline,P., Saez, E. (2014). Where is the Land of Opportunity? The Geography of Intergenerational Mobility in the United States. The Equality of

Opportunity Project.

http://www.equality-of-opportunity.org/assets/documents/mobility_geo.pdf.

Chetty, R., Hendren, N., Katz, L.F. (2015). The Effects of Exposure to Better Neighborhoods on Children: New Evidence from the Moving to Opportunity Experiment. National Bureau of Economic Research (NBER). Working Paper No. 21156.

https://www.nber.org/papers/w21156.

Chicago Department of Public Health (CDPH). 2021. 'The State of Health for Blacks in Chicago.' https://www.chicago.gov/content/dam/city/depts/cdph/CDPH/Healthy\%20Chicago/CDPH_BlackHealth 7c_DIGITAL.pdf.

Children's Defense Fund. (1994). Wasting America's Future: The Children's Defense Fund Report on the Costs of Child Poverty. Beacon Press.

Cohen, S., Glass, D.C., Singer, J.E. (1973). Apartment Noise, Auditory Discrimination, and Reading Ability in Children. Journal of Experimental Social Psychology 9(5): 407-422. https://doi.org/10.1016/S0022$\underline{1031(73) 80005-8}$ 
Cohen, S., Evans, G.W., Krant, D.S., Stokols, D. (1980). Physiological, Motivational, and Cognitive Effects of Aircraft Noise on Children: Moving from the Laboratory to the Field. American Psychologist 35(3): 231243. https://doi.org/10.1037/0003-066X.35.3.231

Currie, J., Hanushek, E., Kahn, E.M., Neidell, M., Rivkin, S.G. (2009). Does Pollution Increase School Absences?. Review of Economics and Statistics 91(4): 682-694.

https://doi.org/10.1162/rest.91.4.682

Currie, J., Heep Ray, S., Neidell, M. (2011). Quasi-Experimental Studies Suggest that Lowering Air Pollution Levels Benefits Infants' and Children's Health. Health Affairs 30(12): 2391-2399. https://doi.org/10.1377/hlthaff.2011.0212

Cutsinger, J.M., Galster, G.C., Santiago. A.M., Stack, L. (2011). Neighborhood Effects on Secondary School Performance of Latino and African American Youth: Evidence from a Natural Experiment in Denver. Journal of Urban Economics. 93. pages 30-48. http://doi.org/10.1016/j.jue.2016.02.004

Duncan, G. J., Boisjoly, J., \& Harris, K. M. (2001). Sibling, peer, neighbor, and schoolmate correlations as indicators of the importance of context for adolescent development. Demography, 38(3), 437-447. https://doi.org/10.1353/dem.2001.0026

Edin, K., Kefalas, M. (2005). Promises I Can Keep: Why Poor Women Put Motherhood Before Marriage. University of California Press.

Entwisle, B. (2007). Putting People into Place. Demography 44(4): 687-703. https://doi.org/10.1353/dem.2007.0045

Eppard, L. M., Blau, F. (2020). Minding the Gap: Explaining Gender Differences in Wages in the United States. Sociation 19(1): 31-35.

Eppard, L. M., Okum, T. S. Everidge, L. (2020a). Differential Opportunity for Men from Low-Income Backgrounds across Pennsylvania. Journal of Working-Class Studies 5(1): 71-100. https://doi.org/10.13001/jwcs.v5i1.6253

Eppard, L. M., Nelson, E., Cox, C., Bonilla-Silva, E. (2020b). Obligations to the Future. Journal of WorkingClass Studies 5(2): 6-69. https://doi.org/10.13001/jwcs.v5i2.6287

Eppard, L. M., Okum, T. S. Everidge, L. (2020c). Inequality of Place and Social Mobility in the United States: Low- and High-Opportunity States. Sociological Viewpoints 34(1): 76-114. http://doi.org/10.26908/3412020_014.

Evans, G. W. (2006.) Child Development and the Physical Environment. Annual Review of Psychology 57: 423451. https://doi.org/10.1146/annurev.psych.57.102904.190057

Evans, G. W., Maxwell, L. (1997). Chronic Noise Exposure and Reading Deficits: The Mediating Effects of Language Acquisition. Environment and Behavior 29(5): 638-656. https://doi.org/10.1177/0013916597295003

Evans, G. W., Kantrowitz. E. (2002). Socioeconomic Status and Health: The Potential Role of Environmental Risk Exposure. Annual Review of Public Health 23(May): 303-331. https://doi.org/10.1146/annurev.publhealth.23.112001.112349

Ewing, E. L. (2020). I'm a Black Scholar Who Studies Race. Here’s Why I Capitalize 'White.' Zora. https://zora.medium.com/im-a-black-scholar-who-studies-race-here-s-why-i-capitalize-whitef94883aa2dd3.

Federal Reserve Bank of St. Louis. 2021a. Employed Full Time: Median Usual Weekly Real Earnings: Wage and Salary Workers: 16 Years and Over: Women. https://fred.stlouisfed.org/series/LES1252882800Q\#0.

Federal Reserve Bank of St. Louis. 2021b. Employed Full Time: Median Usual Weekly Real Earnings: Wage and Salary Workers: 16 Years and Over: Men. https://fred.stlouisfed.org/series/LES1252881900Q.

Future Ready PA Index. (2021). https://futurereadypa.org/. 
Garcia, J. L., Heckman J. J., Ermini Leaf, D., Prados, M.J. (2017). Quantifying the Life-Cycle Benefits of a Prototypical Early Childhood Program. National Bureau of Economic Research. Working Paper 23479. https://www.nber.org/papers/w23479.

Guarino, M. (2021, July 7). Chicago Links Black Residents' Lower Life expectancy to Past and Present Racism. Washington Post.

https://www.washingtonpost.com/national/chicago-links-black-residents-lower-life-expectancy-to-pastand-present-racism/2021/07/06/533e2ed0-de85-11eb-ae31-6b7c5c34f0d6_story.html).

Hambrick-Dixon, P.J. (1985). Effects of Experimentally Imposed Noise on Task Performance of Black Children Attending Day Care Centers near Elevated Subway Trains. Developmental Psychology 22(2): 259-264. https://doi.org/10.1037/0012-1649.22.2.259

Hamner, T., Latzman, R. D., Chan, W.Y. (2015). Exposure to Community Violence, Parental Involvement, and Aggression among Immigrant Adolescents. Journal of Child and Family Studies 24(11): 3247-3257. https://doi.org/10.1007/s10826-015-0128-4

Harding, D. J. (2003). Counterfactual Models of Neighborhood Effects: The Effect of Neighborhood Poverty on Dropping Out and Teenage Pregnancy. American Journal of Sociology 109(3): 676-719. https://doi.org/10.1086/379217

Harding, D. J. (2009). Collateral Consequences of Violence in Disadvantaged Neighborhoods. Social Forces 88(2): 757-782. https://doi.org/10.1353/sof.0.0281

Hays, S. (2003). Flat Broke with Children: Women in the Age of Welfare Reform. Oxford University Press.

Hertz, R. (2006). Single by Chance, Mothers by Choice: How Women are Choosing Parenthood without Marriage and Creating the New American Family. Oxford University Press.

Holzer, H. J., Whitmore Schanzenbach, D., Duncan, G.J., Ludwig, J. (2007). The

Economic Costs of Childhood Poverty in the United States: Subsequent Effects of Children Growing Up Poor. National Poverty Centre Working Paper Series.

http://www.npc.umich.edu/publications/u/working_paper07-04.pdf

Holzer, H. J., Whitmore Schanzenbach, D., Duncan, G.J., Ludwig, J. (2008). The

Economic Costs of Childhood Poverty in the United States. Journal of Children and Poverty 14(1): 4161. https://doi.org/10.1080/10796120701871280

Hymowitz, K. S. (2006). Marriage and Caste in America: Separate and Unequal Families in a Post-Marital Age. Ivan R. Dee.

Kearney, M.S., Levine, P. (2017). The Economics of Nonmarital Childbearing and

the Marriage Premium for Children. Annual Review of Economics 9(August): 327-352.

https://doi.org/10.1146/annurev-economics-063016-103749

Kent, A. H., Ricketts, L.R. (2021). Wealth Gaps between White, Black, and

Hispanic Families in 2019. Federal Reserve Bank of St. Louis.

https://www.stlouisfed.org/on-the-economy/2021/january/wealth-gaps-white-black-hispanic-families2019.

Lanphear, B. P., Hornung, R., Khoury, J., Yolton, K., Baghurst, P., Bellinger, D. C., Canfield, R. L., Dietrich, K. N., Bornschein, R., Greene, T., Rothenberg, S. J., Needleman, H. L., Schnaas, L., Wasserman, G., Graziano, J., \& Roberts, R. (2005). Low-level environmental lead exposure and children's intellectual function: an international pooled analysis. Environmental health perspectives, 113(7), 894-899. https://doi.org/10.1289/ehp.7688

Leventhal, T., \& Brooks-Gunn, J. (2000). The neighborhoods they live in: The effects of neighborhood residence on child and adolescent outcomes. Psychological Bulletin, 126(2), 309-337. https://doi.org/10.1037/0033$\underline{2909.126 .2 .309}$

LexisNexis. (2020). Community Crime Map. https://communitycrimemap.com/.

Massey, D. S., Denton, N.A. (1993). American Apartheid: Segregation and the

Making of the Underclass. Harvard University Press. 
McLanahan, S, Sandefur, S. (1994). Growing Up with a Single Parent: What Hurts, What Helps. Harvard University Press.

McLaughlin, M., Rank, M.R. (2018). Estimating the Economic Cost of Childhood

Poverty in the United States. Social Work Research 42(2): 73-83.

https://doi.org/10.1093/swr/svy007

Opportunity Insights. (2021). Opportunity Atlas. https://www.opportunityatlas.org/.

Organisation for Economic Co-Operation and Development (OECD). (2021a). Income Inequality. https://data.oecd.org/inequality/income-inequality.htm.

Organisation for Economic Co-Operation and Development (OECD). (2021b). Poverty Rate. https://data.oecd.org/inequality/poverty-rate.htm.

Pebley, Anne R., Sastry, N. (2008). 'Neighborhoods, Poverty, and Children's Well-

Being.' In D.B. Grusky (Ed) Social Stratification: Class, Race, and Gender in Sociological Perspective, (pp. 360-371). Westview Press.

Peeples, F., Loeber, R. (1994). Do individual factors and neighborhood context explain ethnic differences in juvenile delinquency? Journal of Quantitative Criminology, 10(2), 141157. https://doi.org/10.1007/BF02221156

Plotnick, R. D., \& Hoffman, S. D. (1999). The Effect of Neighborhood Characteristics on Young Adult Outcomes: Alternative Estimates. Social Science Quarterly,80(1), 1-18. http://www.jstor.org/stable/42863870

Putnam, R. (2015). Our Kids: The American Dream in Crisis. Simon \& Schuster.

Qian, Y. (2017). Gender Asymmetry in Educational and Income Assortative Marriage. Journal of Marriage and Family 79(2): 318-336. https://doi.org/10.1111/jomf.12372

Ransom, M. R., \& Pope, C. A., 3rd (1992). Elementary school absences and PM10 pollution in Utah Valley. Environmental research, 58(2), 204-219. https://doi.org/10.1016/s0013-9351(05)80216-6.

Reardon, S. (2016). School District Socioeconomic Status, Race, and Academic Achievement. Stanford Center for Education Policy Analysis. https://cepa.stanford.edu/content/school-district-socioeconomic-status-raceand-academic-achievement.

Reyes, J. W. (2012). Lead Policy and Academic Performance: Insights from Massachusetts. National Bureau of Economic Research (NBER). Working Paper No. 18327. https://www.nber.org/papers/w18327.

Rojas-Gaona, C. E., Hong, J. S., \& Peguero, A. A. (2016). The significance of race/ethnicity in adolescent violence: A decade of review, 2005-2015. Journal of Criminal Justice, 46, 137-147. https://doi.org/10.1016/j.jcrimjus.2016.05.001

Sackett, C. (2016). Neighborhoods and Violent Crime. HUD. https://www.huduser.gov/portal/periodicals/em/summer16/highlight2.html.

Sampson, R.J. (2012). Great American City: Chicago and the Enduring Neighborhood Effect. The University of Chicago Press.

Sampson, R. J. (2019). Neighbourhood Effects and Beyond: Explaining the Paradoxes of Inequality in the Changing American Metropolis. Urban Studies 56(1): 3-32. https://doi.org/10.1177/0042098018795363

Sampson, R. J., Morenoff, J. D., \& Earls, F. (1999). Beyond Social Capital: Spatial Dynamics of Collective Efficacy for Children. American Sociological Review, 64(5), 633-660. https://doi.org/10.2307/2657367

Sampson, R. J., Morenoff, J. D., \& Gannon-Rowley, T. (2002). Assessing "Neighborhood Effects": Social Processes and New Directions in Research. Annual Review of Sociology, 28, 443-478. http://www.jstor.org/stable/3069249

Sampson, R.J., Sharkey, P., Raudenbush, S. (2008). Durable Effects of Concentrated Disadvantage on Verbal Ability among African-American Children. PNAS 105(3): 845-852. https://doi.org/10.1073/pnas.0710189104 
Sampson, R. J., Winter, A. (2016). The Racial Ecology of Lead Poisoning: Toxic Inequality in Chicago Neighborhoods, 1995-2013. Du Bois Review: Social Science Research on Race 13(2): 261-283.

Sastry, N. (2012). Neighborhood Effects on Children's Achievement: A Review of Recent

Research. In R. King, V. Maholmes (Eds.) The Oxford Handbook of Poverty and Child Development. (pp. 423-447). Oxford University Press.

Schwartz, H.L. (2010). Housing Policy is School Policy: Economically Integrative Housing

Promotes Academic Success in Montgomery County, Maryland. The Century Foundation. https://www.researchgate.net/publication/303150859_Housing_policy_is_school_policy_Economically integrative_housing promotes_academic_success_in_Montgomery_County_Maryland.

Sharkey, P. (2009). Neighborhoods and the Black-White Mobility Gap. Economic Mobility

Project.

https://www.pewtrusts.org/ /media/legacy/uploadedfiles/wwwpewtrustsorg/reports/economic_mobility/ pewsharkeyv12pdf.pdf.

Sharkey, P. (2010). The Acute Effect of Local Homicides on Children's Cognitive

Performance. PNAS 107(26): 11733-11738. https://doi.org/10.1073/pnas.1000690107

Sharkey, P. (2013). Stuck in Place: Urban Neighborhoods and the End of Progress toward

Racial Equality. The University of Chicago Press.

Sharkey, P., Sampson, R.J. (2010). Destination Effects: Residential Mobility

and Trajectories of Adolescent Violence in a Stratified Metropolis. Criminology 48(3): 639-681. http://doi.org/10.1111/j.1745-9125.2010.00198.x

Sharkey, P., \& Elwert, F. (2011). The legacy of disadvantage: multigenerational neighborhood

effects on cognitive ability. AJS; American journal of sociology, 116(6), 1934-1981. https://doi.org/10.1086/660009

Sharkey, P., Schwartz, A.E., Gould Ellen, I., Lacoe, J. (2013). High

Stakes in the Classroom, High Stakes on the Street: The Effects of Community Violence on Students' Standardized Test Performance. Working Paper \#03-13. Institute for Education and Social Policy. New York University.

Sharkey, P., Faber, J.W. (2014). Where, When, Why, and For Whom Do Residential

Contexts Matter? Moving Away from the Dichotomous Understanding of Neighborhood Effects. American Sociological Review (4): 559-579. https://doi.org/10.1146/annurev-soc-071913-043350

Sharkey, P., Sampson, R.J. (2015). Violence, Cognition, and Neighborhood Inequality in America. In R.K. Schutt, L.J. Seidman, M.S. Keshavan (Eds.). Social Neuroscience: Brain, Mind, and Society, (pp. 320-339). Harvard University Press.

Sharkey, P., Besbris, M., Friedson, M. (2016). Poverty and Crime. In D. Brady and L. M. Burton (Eds.) The Oxford Handbook of the Social Science of Poverty. (pp. 632-636). Oxford University Press.

Small, M. L. 2009. Unanticipated Gains. Oxford University Press.

Stansfeld, S. A., Berglund, B., Clark, C., Lopez-Barrio, I., Fischer, P., Ohrström, E., Haines, M. M., Head, J., Hygge, S., van Kamp, I., Berry, B. F., \& RANCH study team (2005). Aircraft and road traffic noise and children's cognition and health: a cross-national study. Lancet. 365(9475), 1942-1949. https://doi.org/10.1016/S0140-6736(05)66660-3

Stebbins, S. (2020, November 13). Mississippi, Louisiana are Among the States with the Most Children Living in Poverty. USA Today.

https://www.usatoday.com/story/money/2020/11/13/how-many-children-live-in-poverty-in-yourstate/114707092/.

Stoddard, S. A., Henly, S. J., Sieving, R. E., \& Bolland, J. (2011). Social connections, trajectories of hopelessness, and serious violence in impoverished urban youth. Journal of youth and adolescence, 40(3), 278-295. https://doi.org/10.1007/s10964-010-9580-z 
United Church of Christ Justice \& Witness Ministries (UCC). (2007). Toxic Wastes and Race at Twenty 1987-2007. https://www.nrdc.org/sites/default/files/toxic-wastes-and-race-at-twenty-19872007.pdf.

United States Bureau of Labor Statistics. (2020). CPI Inflation Calculator. https://www.bls.gov/data/inflation_calculator.htm.

United States Census Bureau. (2020). TIGER/Line Shapefiles. https://www.census.gov/geographies/mapping-files/time-series/geo/tiger-line-file.html.

Virginia Department of Planning and Budget. (2020). Virginia's Budget. https://dpb.virginia.gov/budget/budget.cfm?biennium=2018-2020.

Wheaton, B., Clarke, P. (2003). Space Meets Time: Integrating Temporal and Contextual Influences on Mental Health in Early Adulthood. American Sociological Review 68(5): 680706. https://doi.org/10.2307/1519758

Wilson, W.J. (1996). When Work Disappears: The World of the New Urban Poor. Alfred A. Knopf.

Wilson, V. (2020). Racial Disparities in Income and Poverty Remain Largely Unchanged Amid Strong Income Growth in 2019. Economic Policy Institute. https://www.epi.org/blog/racial-disparities-in-income-and-poverty-remain-largely-unchanged-amidstrong-income-growth-in-2019/.

Wodtke, G. T., Harding, D.J., Elwert, F. (2011). Neighborhood Effects in Temporal Perspective: The Impact of Long-Term Exposure to Concentrated Disadvantage on High School Graduation. American Sociological Review 76(5): 713-736. https://doi.org/10.1177/0003122411420816

Wolfers, J. (2015, May 5). Why the New Research on Mobility Matters: An Economist's View. The New York Times. https://www.nytimes.com/2015/05/05/upshot/why-the-new-research-on-mobility-matters-aneconomists-view.html? r=0 \&abt=0002\&abg=1.

World Inequality Database (WID). (2021). USA. https://wid.world/country/usa/. 